Article

\title{
New Evidence Using a Dynamic Panel Data Approach: Cereal Supply Response in Smallholder Agriculture in Ethiopia
}

\author{
Anbes Tenaye 1,2 (D) \\ 1 School of Economics and Business, Norwegian University of Life Sciences, 1430 Ås, Norway; \\ anbes2003@yahoo.com \\ 2 Department of Agricultural Economics, Hawassa University, Hawassa 05, Ethiopia
}

Received: 15 May 2020; Accepted: 24 July 2020; Published: 30 July 2020

\begin{abstract}
Increasing agricultural production is essential to improving food availability and farm household incomes in developing economies. This study investigated the dynamic supply responses of major cereal crops to price and nonprice factors in Ethiopia using the Ethiopian Rural Household Survey (ERHS) panel dataset from 1994 to 2009. According to the Nerlovian expectation and adjustment approach in conjunction with the system GMM (generalized method of moments) estimator, both the planted areas and produced yields of major crops (teff, wheat, and barley) are influenced by price and nonprice factors in Ethiopia. The supply of major cereal crops is affected positively by their own prices and negatively by the prices of substitute crops. Nonprice factors such as education, farm size, fertilizer, land quality, and precipitation also affect supply of major cereals. Both the short-term and long-term acreage and yield response elasticities of teff and barley are positive. Moreover, the adjustment coefficients are positive for teff, barley, and wheat. The results suggest that Ethiopian farmers are capable of analyzing market signals and responding positively to price increases of staple crops. The findings also imply that the Ethiopian agricultural sector has been responsive to the cereal price increases observed since 2006. The remarkable growth of Ethiopian agriculture over recent decades is partly explained by the increase in agricultural prices. This study recommends that a fine-tuned balance between government interventions and market solutions is important, in addition to improving farmers' agronomic practices, for increasing agricultural production.
\end{abstract}

Keywords: system GMM; acreage response; yield response; supply elasticity; dynamic panel data approach; major cereals; Ethiopia

JEL Classification: D13; Q12; Q18

\section{Introduction}

Increasing agricultural production is indispensable for improving food availability and household incomes in Ethiopia. The Ethiopian economy has experienced notable transformations and challenges to sustained agricultural growth over the past few decades. Over coming decades, the development of the Ethiopian agricultural sector will continue to be challenged by rapid population growth, high economic activity, and urbanization, which lead to increasing food demands. The Ethiopian agriculture sector contributes 33.3\% of the gross domestic product (GDP) (National Bank of Ethiopia 2019), 80\% of occupations, $70 \%$ of the input for industry, $85 \%$ of food supplies, and $81 \%$ of foreign income to the country (African Development Bank Group 2016). However, the sector is dominated by subsistence peasant farming, with a marketed surplus of less than $20 \%$. It is largely rain-fed, with less than $5 \%$ of the land irrigated (Central Statistical Agency 2014). Consequently, the agricultural output is 
tremendously vulnerable to weather conditions, in particular, the amount and distribution of rainfall. Moreover, the Ethiopian agriculture sector contribution to GDP has declined from 41.1\% in 2013/14 to $33.3 \%$ in 2017/2018 (National Bank of Ethiopia 2019). Under all of these challenges, the agricultural sector is considered to be one of the major sectors in addition to service and industry driving growth. Ethiopia seeks to develop into a middle-income country by 2025 (World Bank 2018). These factors call for sustainable development of the agricultural sector in Ethiopia. It is also vital to transform the primary sector to achieve higher productivity and a shift to higher-value products and services.

Recent projections show that there is rising food demand that calls for a significant increase in the availability of staple crops such as cereals, tubers and roots, and pulses (OECD and Food and Agriculture Organization of the United Nations 2016). Among other factors, weak or absent supply responses to market signals by smallholder farmers are vital (Anderson and Masters 2007; Di Marcantonio et al. 2014).

Cereals have received particular deliberation because of their large shares in the diets of most developing countries such as Ethiopia. In Ethiopia, more specifically, the three major cereal crops are teff, wheat, and barley. These crops are individually and jointly important in terms of area coverage, production, and consumption. For example, in July 2006-September 2008, teff, wheat, and barley represented $28 \%, 17 \%$, and $11 \%$, respectively, of the sown area in the country (Central Statistical Agency 2014). Moreover, the five major cereal crops (teff, wheat, maize, sorghum, and barley) are the hub of Ethiopia's agriculture and food sources, accounting for approximately $75 \%$ of the total area cultivated, $29 \%$ of the agricultural GDP in 2005/06 (14\% of total GDP), and $64 \%$ of the calories consumed (Taffesse et al. 2012). Even though considerable growth in cereals in terms of the area cultivated, yields, and production has been recorded since 2000, the yields are low by international standards (Taffesse et al. 2012). Furthermore, increased cereal production and, in particular, sustainable agriculture are generally considered the most important issues of the 2030 agenda contributing to food security and thereby eliminating hunger (Talukder and Blay-Palmer 2017). Hence, cereal production plays a key role in the sustainable development of the Ethiopian agricultural sector.

The food price crisis of 2007-2008 and the recent resurgence of food prices have drawn growing attention to the causes and consequences of food price volatility in the developing world, particularly in sub-Saharan Africa (Headey 2016; Magrini et al. 2017, 2018; Minot 2014; Nakelse et al. 2018). Studies have indicated that staple food prices in sub-Saharan Africa have increased rapidly since 2006, even in US dollar terms (Headey 2016; Magrini et al. 2017; Magrini et al. 2018; Minot 2010). Ethiopia experienced an unprecedented increase in inflation that was among the highest in Africa during the global food crisis (Durevall et al. 2013). In the short term, agricultural supply shocks can affect food inflation, causing large deviations from long-term price trends (Durevall et al. 2013). Food prices increased over 150\% in Ethiopia during 2007-2008, which was a period associated with a surge in global agricultural commodity prices (Minot 2010). Domestic prices of wheat and maize surpassed the import parity price in 2008 by as much as USD300 per ton (Rashid 2010). The nominal prices of teff and wheat rose gradually over the period of 2005-2007 before more than doubling between mid-2007 and mid-2008 (Rashid 2010). At the same time, the global prices of maize, wheat, and soybeans more than doubled, while global rice prices tripled between January 2006 and early 2008 (Minot 2010). However, the food price increases in Ethiopia were larger than the increases in the world markets for the same commodities (Minot 2010).

Previous food price increases in Ethiopia were different from those in many other developing countries (Rashid 2010). The domestic price increase in Ethiopia was not related to the global price increase, unlike in other countries. Instead, the price increase began with rapid growth in the money supply relative to the overall economic growth. This trend was later aggravated by a large negative balance of payments that resulted in government rationing of foreign exchange and increases in fuel prices.

High and unstable food prices are one of the major policy concerns in Ethiopia (Rashid 2010; Worako 2012). Accordingly, the government has responded with various policies, such as banning 
certain grains from export, and tariff reductions on imported foods, to lower the domestic prices. However, these policies hinder local farmers from getting a better price and reduce biodiversity. The policy actions reflect the concerns of the government regarding the impact of food price increases on the poor, who spend an average of $54 \%$ of their household income on food (World Bank 2013). Increased food prices adversely affect urban consumers and net buyers, at least in the short term. However, the increase in food prices is an opportunity and incentive for agricultural producers, particularly net sellers, who experience structural and functional challenges in increasing production and productivity. It is widely acknowledged that increased agricultural prices create incentives for farmers to increase production through the increased use of inputs and the adoption of new technologies (Ampadu-Ameyaw and Awunyo-Vitor 2014; Bellemare et al. 2013; Magrini et al. 2017; Sadoulet and Janvry 1995; Thiele 2003). Additionally, farm production and productivity could be increased via technological progress and scale efficiency changes (Tenaye 2020a), and by improving farmers' technical efficiency (Tenaye 2020b). Moreover, the response to increased prices also depends on structural factors, such as the nature of smallholders, the availability of technologies, and the functioning of input markets.

The supply responses of Ethiopian farmers have been studied by many scholars. These studies have used aggregate time-series data such as export supply responses for coffee (Alem 1996; Dercon and Ayalew 1995) and supply responses for food grains (Abebe 1998; Zerihun 1999). Studies have also used time-series data with an error-correction model (Alemu et al. 2003), applied the profit function approach (Abrar and Morrissey 2006; Abrar et al. 2004a, 2004b), and used panel data (Abrar and Morrissey 2006).

These empirical supply response studies can be criticized on four grounds: the approach used, the modeling technique applied, the estimation technique employed, and the type of data used. First, the majority of studies applied the supply function approach, which is derived from the profit-maximizing framework (Abrar and Morrissey 2006; Abrar et al. 2004a, 2004b). This approach encompasses a combined estimation of the output supply and input demand functions (Mythili 2012). Thus, the supply function approach uses information regarding input prices and quantities, which are not readily available in less-competitive input markets. Second, most empirical studies overlooked the dynamic nature of supply responses. The estimation of the Nerlovian expectation model without accounting for the dynamic nature of the supply response function is likely to produce a biased result due to the correlation of the lagged dependent variable with the unobserved individual effects (Nickell 1981). Third, most studies used ordinary least squares (OLS) estimation (Abrar et al. 2004a) and maximum likelihood estimation (Abrar and Morrissey 2006; Abrar et al. 2004b). A possible correlation between the lagged dependent variables and the error terms likely produces biased results in a panel setting if OLS estimation is used (Baltagi 2008). Fourth, many studies used time-series data that fail to show the panel nature of the supply response. However, panel data have a distinct advantage in controlling household and temporal variations for dynamic models. Some past studies used a small number of observations to estimate the supply response. These concerns may have implications for the validity of the studies.

The main objectives of this study were to estimate the acreage and yield responses to price and nonprice factors and to estimate short-term and long-term elasticities of the three major cereals in Ethiopia. This study also aims to address the aforementioned concerns by using an extended Nerlovian model (Askari and Cummings 1977; Nerlove 1956), making use of the dynamic nature of supply response, the system generalized method of moments (GMM) estimator, panel data, additional relevant variables, and a relatively larger number of observations.

The remainder of the article is organized as follows. The second section introduces the methodology. The third section describes the results and discussion. The last section describes the major findings and policy implications. 


\section{Methodology}

This section provides a brief overview of the data, the theoretical framework, the Nerlovian supply response model, and the estimation strategy.

\subsection{Data Compilation}

The data used in this study were obtained from the Ethiopia Rural Household Survey (ERHS). The ERHS is a unique longitudinal dataset covering rural Ethiopia. Addis Ababa University (AAU), the Centre for the Study of Africa Economics (CSAE) at Oxford, and the International Food Policy Research Institute (IFPRI) collaboratively collected the data for these rounds. Household panel data were collected in 1994, 1999, 2004, and 2009 from four major regions: Amhara; Oromiya; Southern Nations, Nationalities, and Peoples (SNNP); and Tigray. Each of these four regions is one of the nine administrative regions in the country, and together, they account for approximately $86 \%$ of the Ethiopian population. This survey covers 15 of the 389 woredas $^{1}$ (districts) and 18 farmers associations (FAs). The data were compiled into 1323 households producing the major cereals and 3170 observations. One FA was selected from each of the woredas ${ }^{2}$. The surveys were conducted on a stratified sample over the country's three major agricultural farming systems that are found in five agroecological zones (Dercon and Hoddinott 2004). The first agroecological zone is known as the northern highlands. This zone includes two villages in the Tigray region, Geblen and Harresaw, and one from the Amhara region, Shumsheha. The northern highlands are characterized by poor resource endowments, adverse climatic conditions, and frequent droughts. The central highlands agroecological zone is represented by the villages of Dinki, Yetmen, and Debre Birhan, which are located in the Amhara region, and Turufe Ketchema in the Oromiya region. The Arussi/Bale agroecological zone includes the villages of Koro Degaga and Sirbana Godeti, which are both in Oromiya. Adele Keke is the sole survey site found in the Hararghe agroecological zone of Oromiya. The remaining five villages of Imdibir, Aze Deboa, Gara Godo, Adado, and Doma are found in the enset-growing agroecological zone located in the SNNP region. Sole cropping is the most common agricultural practice in the study areas, followed by mixed cropping. The panel dataset is organized based on four survey rounds conducted in the areas described above. Total rainfall data (in $\mathrm{mm}$ ) from the National Meteorological Service Agency of Ethiopia (NMSAE 2014) are included in the Nerlovian output supply function.

The values of outputs are calculated based on the yields and prices of the sample crops. Because most variables are measured in local units, all local measurement units were converted to a common standard unit. This process enables us to aggregate and compare farm outputs and inputs within and between households. All value measures are expressed based on the 1994 prices using the producer price index for farm products and some of the inputs.

Table 1 provides descriptive statistics of the major variables of interest. Land is the basic asset of farmers in Ethiopia. The mean farm size is approximately 1.5 ha per household, with 0.01 ha and 11.5 ha being the minimum and maximum sizes, respectively. The soil fertility of the plots is medium on average, and approximately $47 \%$ of the farms have "good" soil fertility. Another indicator of soil fertility is the land quality inde ${ }^{3}$, which takes the soil fertility and slope into account. On average, farms have a land quality index of 6.49 , with a minimum of 1 and a maximum of 9 . Approximately $75 \%$ of rural households operated on 2 ha of land or less, $50 \%$ cultivated farms operated on less than 1.2 ha,

1 A woreda is a governmental administrative unit below zones in a given region and is equivalent to the designation of a district elsewhere.

2 The Debre Birhan woreda in the Amhara region is large and includes four FAs that were included in the sample.

3 The average land quality index is calculated as a product of the natural conditions of two indices that assign a value of 3 if the slope is flat and a value of 3 if the land is fertile in terms of mineral content. A high index value indicates better soil fertility. The average land quality is best in terms of slope and mineral content when given a value of 9 , with a value of 1 indicating the lowest land quality evaluated at the household level. 
and $25 \%$ operated on land totaling 0.5 ha or less during the 1994-2009 cropping seasons. The average number of plots per household was 5 . Thus, the farmers have immensely fragmented cultivated land.

Table 1. Descriptive statistics of variables in agricultural production.

\begin{tabular}{|c|c|c|c|}
\hline Variable Code & Description & $\%$ With a Value of 1 & Mean \pm SD \\
\hline Sex & 1 if the household head is male and 0 otherwise & 79.87 & \\
\hline Family size & Total number of family members & & $6.80 \pm 3.04$ \\
\hline Age & Age of the household head (years) & & $49.74 \pm 15.39$ \\
\hline Education & 1 if the household head is literate and 0 otherwise & 37.57 & \\
\hline Farm size & $\begin{array}{c}\text { Total farm size operated by the household } \\
\text { (hectares) }\end{array}$ & & $1.51 \pm 1.18$ \\
\hline Soil fertility & 1 if the fertility status is good and 0 otherwise & 47.08 & \\
\hline Labor & Adult equivalent unit (AEU) & & $4.07 \pm 2.22$ \\
\hline TLU & Tropical livestock unit owned (TLU) & & $3.42 \pm 4.04$ \\
\hline Fertilizer & $\begin{array}{c}\text { Total real value of fertilizer expenditure of the } \\
\text { household (Birr) }\end{array}$ & & $145.33 \pm 238.35$ \\
\hline Credit & $\begin{array}{c}\text { Total real value of credit taken by the } \\
\text { household (Birr) }\end{array}$ & 52.49 & \\
\hline Extension & $\begin{array}{l}1 \text { if the household is visited by an extension } \\
\text { agent for technical support and } 0 \text { otherwise }\end{array}$ & 50.40 & \\
\hline Hoe & The number of a hoe(s) owned by the household & & $1.26 \pm 1.56$ \\
\hline AEZ & $\begin{array}{l}\text { Agroecological zone: } 1 \text { if the AEZ is the northern } \\
\text { highlands, } 2 \text { for the enset-growing area (hoe } \\
\text { farming), } 3 \text { for Hararghe (oxen farming), } 4 \text { for } \\
\text { Arussi/Bale and } 5 \text { for the central highlands }\end{array}$ & $14,33,8,13,32$ & \\
\hline Precipitation & Rainfall amount $(\mathrm{mm})$ & & $85.64 \pm 28.51$ \\
\hline Land quality & Land quality index & & $6.49 \pm 2.29$ \\
\hline Output value & $\begin{array}{c}\text { Sum of the real values of crops and } \\
\text { livestock (Birr) }\end{array}$ & & $3121.46 \pm 4211.12$ \\
\hline
\end{tabular}

Source: authors' calculations. SD = standard deviation. Notes: Monetary values are expressed in 1994 prices using the producer price index. Birr is the Ethiopian currency: 1 USD = 5.22 birr in 1994, 1 USD = 7.81 birr in 1999, 1 USD $=8.34$ birr in 2004 and 1 USD = 11.53 birr in 2009 when the data were collected (National Bank of Ethiopia 2015). Subscripts for household number (i) and year ( $\mathrm{t}$ ) are omitted to improve readability.

Education plays an important role in the enhancement of the utilization of farm inputs and affects the willingness to adopt new technologies. However, only approximately $38 \%$ of household heads have attended some schooling that enables them to read and write. This finding shows that the level of education in the study area is extremely low.

Water from either rainfall or irrigation is one of the most important inputs for agricultural production but is rarely considered as an input in Ethiopian agriculture. However, rain-fed agriculture dominates Ethiopian farming, while only approximately 4 to $5 \%$ of potentially irrigable land is irrigated (Awlachew et al. 2010). The rainfall amount and distribution are also important factors in agricultural production, although only the amount is used in this analysis. Rainfall is expected to have a positive effect on the yield supply response because the crops studied are rain-fed. Other related factors, such as the soil fertility, labor, extension, hoe and fertilizer, and the water-retaining capacity of the soil, also affect production. Information on some of these attributes would be useful for explaining the impact on the output supply.

\subsection{Theoretical Framework}

A fundamental principle of economics is the theory of supply, which states that producers produce more quantity as a result of an increase in the price when other factors are kept constant. In other words, smallholder farmers are encouraged to produce more of the product if they would expect a higher price, as indicated by the "producer theory". Supply analysis is one of the commonly used techniques in the literature that evaluates production responses to prices (output and input prices) and nonprice factors (such as policy, environment, and household characteristics). The theory of the 
firm is the basis from which supply analysis is derived (Colman 1983). This production process can be assessed using production, cost, distance, or profit functions.

Supply analysis can be studied using two main approaches: normative (programming) and positive (econometric). The positive approach has two subgroups: primal (structural) and dual (reduced) approaches (Colman 1983; Sadoulet and Janvry 1995). The primal approach involves estimation of the structural production function or stochastic frontier (Coelli et al. 2005), whereas the dual approach involves estimation of the cost or profit functions.

The agricultural supply is typically modeled as the response of the crop-sown area (or yield produced) as a function of price and nonprice factors (Askari and Cummings 1977). The three price-expectation models commonly used in the literature to study supply responses are the naïve price-expectation model, the adaptive price-expectation model, and the rational price-expectation model. These models vary primarily in their assumptions of how farmers structure their price expectations (Haile et al. 2015). The naïve price-expectation model assumes that farmers do not have a learning process in structuring their price expectations and, instead, they make their crop area decisions exclusively based on the market price realized in the earlier period (Ezekiel 1938). The adaptive price-expectation model allows farmers' crop area allocation decisions to be responsive to the expected price and the prices realized in all earlier periods (Nerlove 1956). The rational price-expectation model assumes that farmers adjust their price expectations based on all available information in the market (Askari and Cummings 1977; Muth 1961). Rational price-expectation relationships may not be straightforward, as they are determined by both supply and demand equations, which require extra data (Nerlove 1979).

The Nerlovian supply response model (the Nerlovian adaptive expectation and the partial-adjustment model) is the most commonly used (Askari and Cummings 1977; Khan et al. 2019; Magrini et al. 2018; Ogundari 2018; Shonkwiler and Hinckley 1985; Wickens and Greenfield 1973; Zhai et al. 2019).

\subsection{The Nerlovian Supply Response Model}

Following the most common approach in previous studies, this study also employs a Nerlovian framework to investigate how the supplies of major cereal crops in Ethiopia respond to price and nonprice factors. The Nerlovian partial-adjustment model specifies the outcome variable of interest (sown area and produced yield of the major cereal crops in this study) as a function of the expected output price, sown-area adjustment, and a set of nonprice variables. All continuous variables are converted to logarithms and thus coefficients can be interpreted as elasticities. The commonly adopted Nerlovian model consists of three "structural" equations (Askari and Cummings 1977; Nerlove 1979):

$$
\begin{gathered}
\mathrm{A}_{\mathrm{t}}^{\mathrm{d}}=\alpha_{0}+\alpha_{1} p_{\mathrm{t}}^{\mathrm{e}}+\alpha_{2} \mathrm{Z}_{\mathrm{t}}+\mathrm{v}_{\mathrm{t}} \\
\mathrm{P}_{\mathrm{t}}^{\mathrm{e}}-\mathrm{P}_{\mathrm{t}-1}^{\mathrm{e}}=\beta\left(\mathrm{P}_{\mathrm{t}-1}-\mathrm{P}_{\mathrm{t}-1}^{\mathrm{e}}\right), 0 \leq \beta \leq 1 \\
\mathrm{~A}_{\mathrm{t}}-\mathrm{A}_{\mathrm{t}-1}=\gamma\left(\mathrm{A}_{\mathrm{t}}^{\mathrm{d}}-\mathrm{A}_{\mathrm{t}-1}\right), 0 \leq \gamma \leq 1
\end{gathered}
$$

where $A_{t}^{d}$ is the desired cultivated area (can be yield) in period $t$; $p_{t}^{e}$ is the expected prices of the crop and other competing crops for period $t ; Z_{t}$ is a set of other exogenous shifters, such as rainfall, land quality, fertilizer, farm size, education; $v_{t}$ accounts for unobserved random factors affecting the area being planted with a specific crop; $\alpha_{i}$ is the parameter to be estimated; $P_{t-1}$ is the lagged price that prevails when decision making for production in period toccurs; $\beta$ is the adaptive-expectation coefficient; $A_{t}$ is the actual area planted with a specific crop; and $\gamma$ is the partial-adjustment coefficient. The desired cultivated area of a specific crop $\mathrm{c}$ for individual household $\mathrm{i}$ during period $\mathrm{t}$ is a function of the expected output prices and many other exogenous factors. Similarly, the desired output of a certain crop $\mathrm{c}$ for individual household i during period $\mathrm{t}$ is a function of the expected output prices and 
many other exogenous factors (Braulke 1982; Diebold and Lamb 1997). Either the harvested tonnage or planted acreage could be used as the output variable (Bond 1983).

The price that the producer expects to receive at harvest time cannot be observed. Therefore, one must specify a model that explains how agents form expectations based on actual and past prices, as well as other observable variables. For example, farmers adjust their expectations as a fraction of the deviation between their expected price and the actual price in the last period, $t-1$, via Equation (2). Because a full adjustment to the desired allocation of land may not be possible in the short term, the actual adjustment in the area is only a fraction $\gamma$ of the desired adjustment in Equation (3). Further details on the derivation of equations can be found in Appendix A.

\subsection{Estimation Strategy}

There are two common approaches for estimating a supply response in the economics literature ${ }^{4}$. The first approach is the Nerlovian expectation model, which is used to analyze both the rate and level of adjustment of the actual acreage. This acreage adjustment is made based on the expected yield. The second is the supply function approach, which is derived from the profit-maximizing framework. This approach encompasses the combined estimation of the output supply and input demand functions. The supply function approach requires information on all of the input prices and quantities, which were not readily available for the current study. Moreover, the agricultural input markets in Ethiopia, such as land and labor, neither exist nor function in a competitive market. Thus, I use the Nerlovian expectation model to estimate the supply response to the increase in output prices and nonprice factors over the study period. Just (1993) and Sadoulet and Janvry (1995) review these approaches. They conclude that the Nerlovian approaches are well suited to handle these dynamic processes in the supply response.

The pioneering work of Nerlove (1958) on supply responses also enables us to determine short-term and long-term elasticities. The Nerlovian model offers flexibility when introducing nonprice shift variables into the model. Production decisions must be based on the prices that farmers expect to receive during the harvest period after several months. Nerlovian models are built to examine farmers' output reactions based on price expectations and partial area adjustments (Nerlove 1958). The crop supply response models can be framed in terms of yield and/or area responses. For instance, the desired crop area to be planted in period $t$ is a function of the expected output prices Pe and a vector of exogenous variables Z (Braulke 1982; Diebold and Lamb 1997).

This study used a Nerlove-type model to specify the production responses to output price changes. Equations (4) and (5) are the reduced form of the Nerlovian model. These equations describe the current level to which the area (or yield) is determined by the previously expected level of prices, a set of nonprice variables, the past level of the area (or yield), and the disturbance term. Equations (4) and (5) present the theoretical description of the Nerlovian model, and their final form used for empirical estimation must capture the relevant factors underlying the agricultural supply. Hence, introducing these factors into the agricultural supply function equations (acreage (4) and tonnage (5)) could allow them to be rewritten as Equations (4) and (5), respectively.

$$
\begin{aligned}
& A_{\text {cit }}=a_{0}+a_{1} P_{\text {cit-1 }}+a_{2} Z_{\text {cit }}+a_{3} A_{\text {cit-1 }}+u_{\text {cit }} \\
& Y_{\text {cit }}=a_{0}+a_{1} P_{\text {cit-1 }}+a_{2} Z_{\text {cit }}+a_{3} Y_{\text {cit-1 }}+u_{\text {cit }}
\end{aligned}
$$

where,

4 The agricultural household model is another choice for characterizing the complexity of household supply behaviors in response to price incentives (Singh et al. 1986). This alternative approach requires information on household consumption, input prices, and the input quantities used for each crop (e.g., labor). The Nerlovian expectation model is used here because the primary concern of this study is to estimate the production response to the output price incentive and nonprice factors rather than the overall behavioral responses. 
$\mathrm{A}_{\text {cit }}=$ area of the crop $\mathrm{c}$ at time $\mathrm{t}$ for household $\mathrm{i}$

$\mathrm{P}_{\text {cit- } \mathrm{t}}=$ current price and price lagged by one period for the crop $\mathrm{c}$ for household $\mathrm{i}$

$Z_{\mathrm{cit}}=$ other exogenous variables (such as the total farm size, average rainfall, land quality, education, prices of other crops, and crop dummies)

$\mathrm{A}_{\mathrm{cit}-1}=$ area lagged by one period for the crop $\mathrm{c}$ for household $\mathrm{i}$

$\mathrm{t}=$ production year under consideration

$\mathrm{u}_{\mathrm{cit}}=$ error term of the crop $\mathrm{c}$ at time $\mathrm{t}$ for household $\mathrm{i}$.

Similarly,

$\mathrm{Y}_{\mathrm{cit}}=$ output of the crop $\mathrm{c}$ at time $\mathrm{t}$ for household $\mathrm{i}$

$\mathrm{P}_{\text {cit- } \mathrm{t}}=$ current price and price lagged by one period for the crop $\mathrm{c}$ for household $\mathrm{i}$

$\mathrm{Z}_{\mathrm{cit}}=$ other exogenous shifters (such as the area of the crop, average rainfall, land quality, education, prices of other crops, and crop dummies)

$\mathrm{Y}_{\mathrm{cit}-1}=$ output lagged by one period for the crop $\mathrm{c}$ for household $\mathrm{i}$

$\mathrm{t}=$ production year under consideration

$\mathrm{u}_{\mathrm{cit}}=$ error term of the crop $\mathrm{c}$ at time $\mathrm{t}$ for household $\mathrm{i}$.

To capture the full supply response, therefore, both yield response models with the acreage response $\left(A_{t}\right)$, and yield $\left(Y_{t}\right)$ are estimated using Equations (4) and (5), respectively. The area response model is influenced by one additional regressor (total farm size), in contrast to the yield response model, which is also influenced by one additional regressor (area of the crop). Education is an important yield-augmenting input, in addition to rainfall. The area and yield response models give us short- and long-term area and yield elasticities, respectively. Adding the area and yield elasticities yields the supply elasticities.

The reduced form is a distributed lag model with lagged dependent variables taken as independent variables. The coefficient of each explanatory variable gives short-term elasticities, and the long-term elasticities are obtained by dividing the short-term elasticities by $\left(1-a_{3}\right)$ (i.e., the adjustment coefficient), where $a_{3}$ denotes the coefficients of the lagged dependent variables (Mythili 2012; Sadoulet and Janvry 1995). The assumption underlying this model is that all long-term elasticities exceed the short-term elasticities. If the adjustment coefficient is close to 1, this implies that the farmers' adjustment of the actual acreage to the desired acreage occurs quickly. If the adjustment coefficient is close to zero, then the adjustment occurs slowly. The prices are revised in each period in proportion to the difference between the last period's observed price and the previous period's expectation. $p_{t}^{e}$ is the average price expected to prevail in all future periods. The farmer responds rationally based on the average "normal" price level rather than the price forecast.

Modeling the supply response is a two-stage procedure. First, farmers allocate plots to crops based on expected prices. Second, the yield is determined based on the plot area, other inputs, and weather conditions. Generally, farmers revise the use of other inputs after they allocate a specific crop to a plot, and the overall input changes will be reflected in the yield. Thus, it is realistic to assume that both the area planted and the yield produced can be used as proper dependent variables to study farmers' responses to output prices and nonprice factors. However, the yield harvested is subject to greater fluctuation than is the area planted because of uncertain random factors, such as the temperature, rainfall, input use, and management. To understand the farmers' behaviors in crop allocation choices, the area response is more appropriate than the yield response for measuring the supply response.

Overall, the Nerlovian framework is preferred over other models for analyzing producer behaviors in developing countries for at least three reasons. The first is that the left-hand-side variable is dynamic. The second is that it enables the computation of short-term and long-term responses and the speed of adjustment in moving from the actual to the desired level of area and yield. The third is that the alternative model requires detailed data on input prices and quantities, which are difficult to obtain for developing countries due to market failures. 
Both the acreage and yield Equations (4) and (5) represent dynamic panel models, whereby the dependent variable is a function of its lagged values, among other factors. Applying an OLS or fixed effects (FE) estimation for a dynamic panel model leads to a dynamic panel bias due to the correlation of the lagged dependent variable with the unobserved individual effects (Nickell 1981). In this case, therefore, the difference GMM and system GMM are two closely related dynamic panel data model estimators that were first developed by Holtz-Eakin et al. (1988). Arellano and Bond (1991) developed a difference GMM estimator, also called the "Arellano-Bond" estimator, to estimate a dynamic panel model by differencing and using lagged endogenous and other exogenous variables as instruments (Roodman 2009). Arellano and Bover (1995) and Blundell and Bond (1998) further developed the Arellano-Bond/Arellano-Bover estimation methods into a method collectively known as the system GMM. The system GMM technique transforms the instruments themselves to make them exogenous to the fixed effects (Roodman 2009). The system GMM estimator allows efficiency gains over the differenced GMM estimator, provided that the initial differences of the instrument variables are uncorrelated with the fixed effects (Blundell and Bond 1998).

In general, the system GMM estimation method is suitable for data with few periods and many unit (small T and large N) panels, lagged dependent variables, fixed effects, heteroscedastic variance, autocorrelated errors, and endogenous regressors (Roodman 2009). The chosen variables are believed to be good predictors of planned supplies of teff, wheat, and barley. Both price and nonprice factors such as the real producer prices of their own and substitute crops, rainfall, farm size, land quality, and education are included. Empirical evidence shows that the dynamics of supply can be better estimated using system GMM (Blundell and Bond 1998; Brockhaus et al. 2015; Roodman 2009). System GMM does not assume normality and controls for heteroscedasticity, unlike the conventional OLS method (Jaunky 2013). The Nerlovian model, which addresses the analysis of both the rate and the level of adjustment of the actual acreage towards the desired acreage, does not require input prices or quantities. These estimators are appropriate for the current study because the left-hand variables of Equations (4) and (5) are dynamic, and the data have a short panel. These estimators also separate the fixed effects from idiosyncratic errors that are heteroscedastic and correlated. Autocorrelation, heteroscedasticity, and contemporaneous correlation cause estimation problems in panel observation. Furthermore, this method enables the introduction of variables as strictly exogenous, predetermined, or endogenous (Roodman 2009). In this study, the lagged dependent variables (area and yield) and the price variables (the crop prices) treated as predetermined variables. Hence, the GMM estimation generates the internal instruments (instrument variables) via data-generating processes (i.e., orthogonal deviations) and lags of the price of teff, barley, wheat, and the area of the crop. The other exogenous instruments are precipitation, lagged precipitation, and time dummy. Thus, the possible endogeneity of variables in my models is controlled.

In Equations (4) and (5), the areas allocated to a specific crop and yield produced, respectively, are treated as endogenous variables, assuming that these variables are endogenous to prices, rainfall, the total farm size owned by the household (in the case of the area response), the area allocated to a specific crop (in the case of tonnage response), the land quality, and education. In both equations, contemporaneous rainfall enters all of the models as a strictly exogenous variable. Thus, I use the system GMM method to estimate the dynamic supply models, as implemented in the STATA $13^{\circledR}$ module xtabond2 (StataCorp 2013), which is used to estimate Equations (4) and (5) for acreage and yield responses of three major cereals.

\section{Results and Discussion}

This section provides the trends of price, area, and the output of major cereals, and the estimation results of the Nerlovian adaptive-expectation and partial-adjustment models using a dynamic panel data approach and system GMM estimation techniques. 
3.1. The Trends of Price, Area, and Output of Major Cereals in Ethiopia from 1994 to 2009

The figures depict the trends of the price in birr per $\mathrm{kg}$ (Figure 1), area in ha (Figure 2), and output in birr (Figure 3) of major cereals in Ethiopia from 1994 to 2009. As shown in Figure 1, the prices of major crops began to increase as early as 2004, with the sharpest increase occurring in the years 2006 to 2008 .

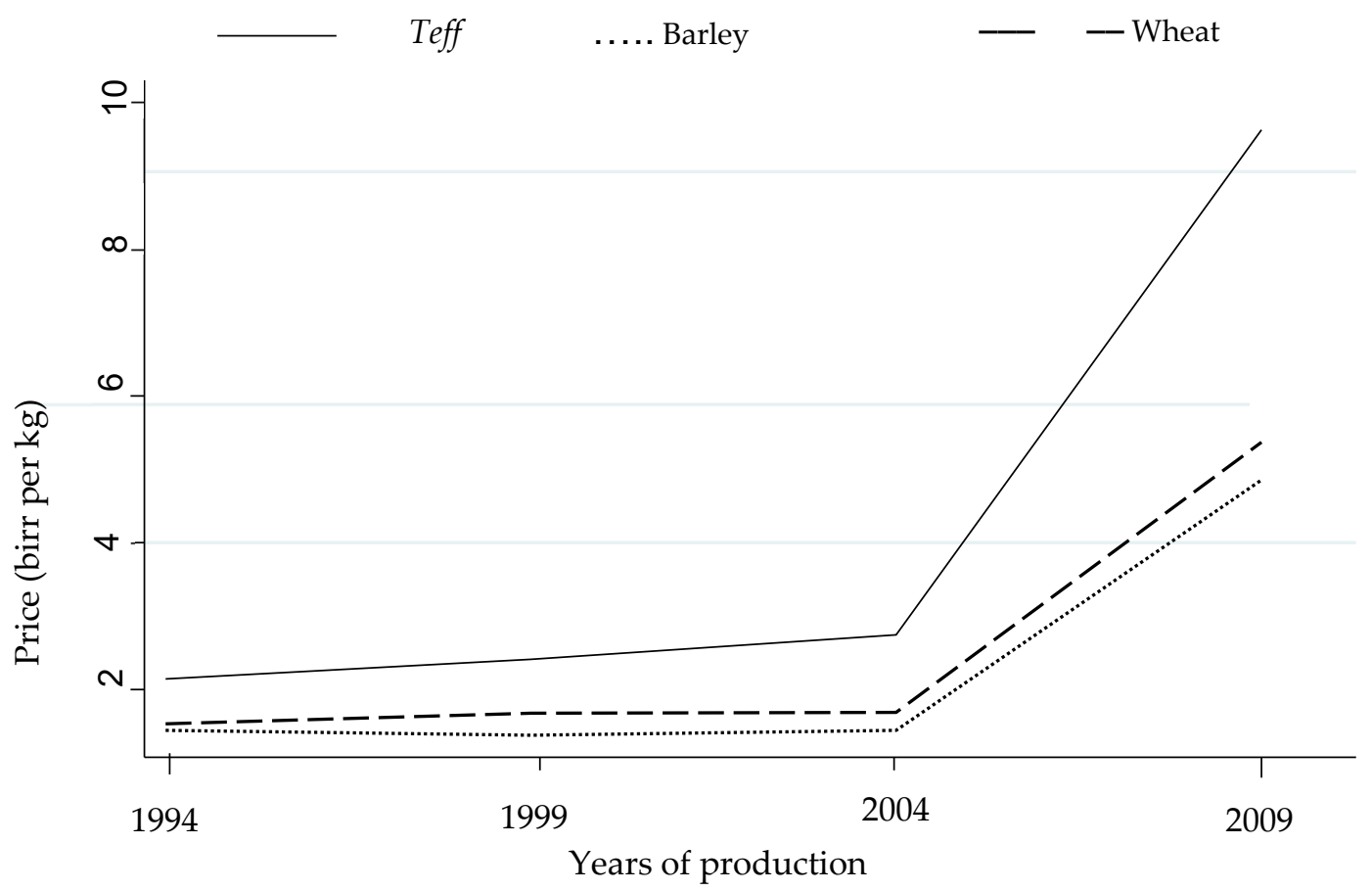

Figure 1. Price trends of major crops in Ethiopia (1994-2009).

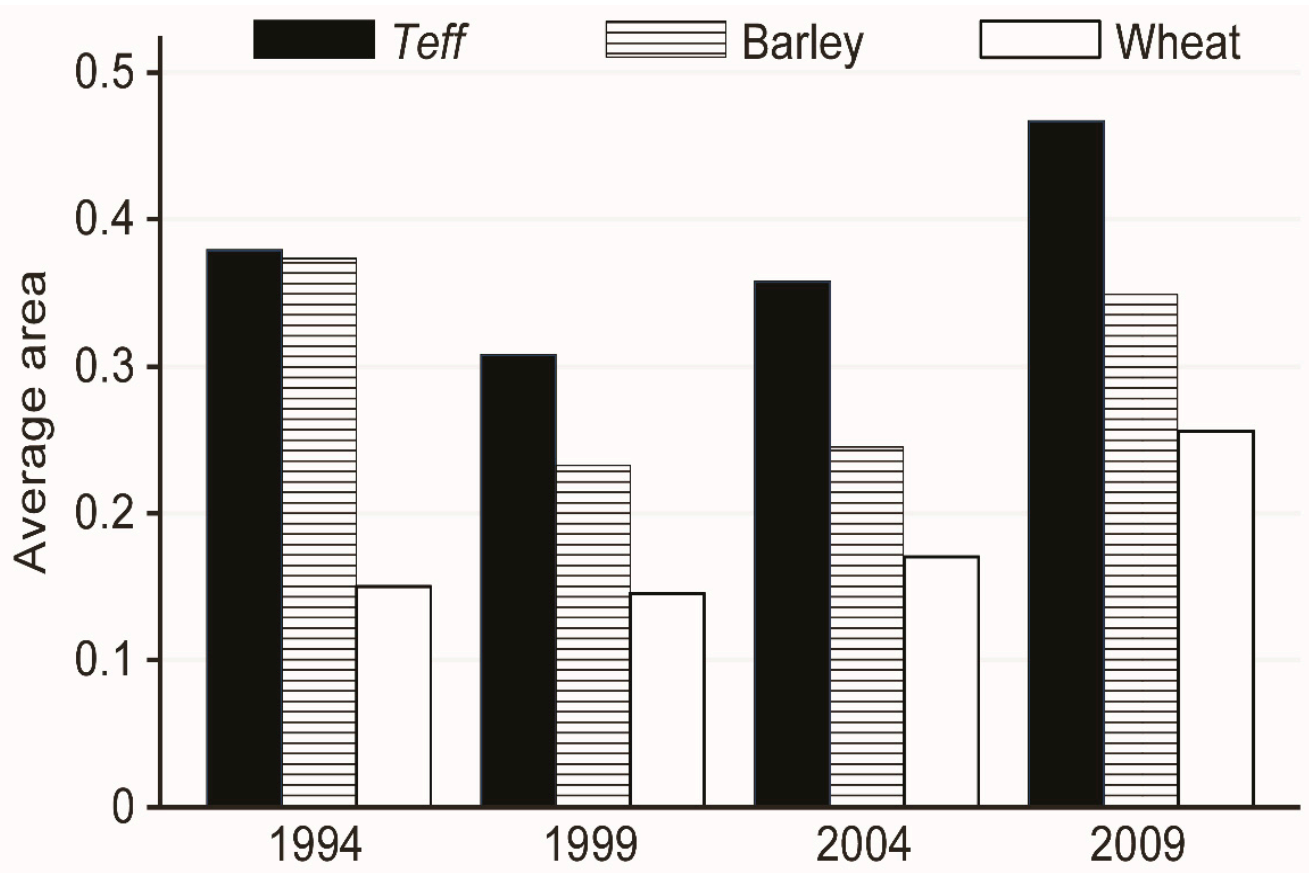

Figure 2. Average area (ha) cultivated for major cereal ${ }^{5}$ crops in Ethiopia (1994-2009). 


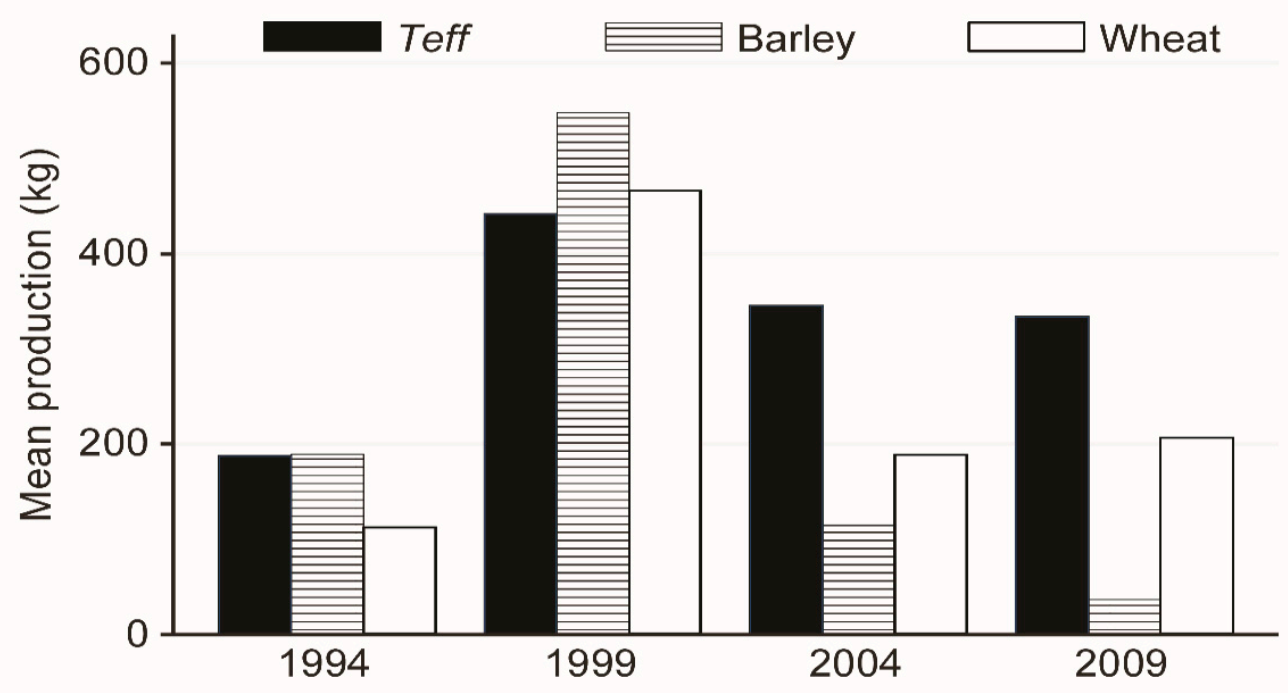

Figure 3. Average production (kg) of major crops in Ethiopia (1994-2009).

Teff is a staple food for more than 110 million of the country's people. Teff is typically banned from export as part of the food price stabilization measures taken by the government in Ethiopia. Other cereals are rarely exported because they are neither competitive nor provide a sufficient surplus for export. On the contrary, wheat is imported for more than $15 \%$ of the country's production annually.

Households decide which crops to plant based on the price expected for the crops and the availability of other crops and vegetables for their consumption, among other factors. The area allocated to teff, barley, and wheat evidently increased during the study period (Figure 2).

As shown in Figure 3, there are variations in the outputs of the major cereals over time. The yield variation depends on the input use, disease, weather conditions, management, and other factors. Farmers may shift the crop to a larger but marginal piece of land, and there may be an increase in the area but a decrease in the output when all other factors remain constant. This partly explains the inverse relationship between the area and the output.

Most Ethiopian farmers have limited financial resources, which limit the yield per hectare, as the use of fertilizers is quite low. Additionally, a considerable proportion of their harvest is sold immediately following harvest when prices are low. Early sales are conducted primarily to pay for fertilizer credit and to cover regular household expenses.

Recently, producer cooperatives have attempted to fill this financial gap for some specific cash crops in a few areas. For example, coffee producers in southern regions form coffee producer cooperatives that buy coffee from farmers at a reasonable price and sell it during a later period. The cooperatives redistribute profits to their member farmers based on the amount sold by the farmers.

\subsection{Estimation Results of the Nerlovian Adaptive-Expectation and Partial-Adjustment Models}

This study examined the extent to which the production of major cereal crops responds to price and nonprice factors in Ethiopia. Both acreage and yield responses to an increase in output prices and nonprice covariates were estimated using a panel database from Ethiopia. To check the validity of the

Cereals are annual crops, while most cash crops are perennial crops. Cereals need one season until harvest and live for only one season during each year. Perennial crops require two or more seasons until the first harvest, after which they can be harvested for several years until they expire. For example, Coffea Arabica, which is known as Arabica coffee, bears fruit after three to five years and produces fruit for approximately 50 to 60 years (for a maximum of 100 years). Chat plants yield the first harvest in 2 to 3 years. Chat harvesting can occur 2-3 times a year for 50 or more years. According to Tenaye and Geta (2009), mature enset plants (4 to 7 years old) are harvested mainly to prepare staples known as kocho and bulla, whereas immature enset plants (less than 2 years old) are harvested to prepare amicho. All of these perennial crop areas require a long period to be converted to other crops and are much less flexible than annual crops in terms of shifting area coverage. 
preferred models and specifications, the Sargan test was employed for the overidentification restrictions, the Hansen test was used for the exogeneity of the instruments, and the Arellano-Bond test was applied for autocorrelations. Furthermore, robust standard error estimates were computed for the presence of any pattern of heteroscedasticity and autocorrelation within the panels. Unobserved heterogeneity was also controlled using panel datasets. The difference-in-Hansen test reports the $p$-values for the validity of the additional moment restriction necessary for system GMM. The autocorrelation test reports the $p$-values for the first-order autocorrelation of the first-differenced residuals. The test results are provided at the bottom of Table 2. The null hypothesis that the population moment conditions are correct is not rejected; thus, the validity of the instruments is verified using the Hansen test. The other test statistic reported is the Arellano-Bond test for autocorrelation of all acreage and yield models, which looks at the second-order correlation to test for first-order serial correlation in levels of the error term. The F-test supports the overall fit of the dynamic model. All of these tests indicated the consistency of the system GMM estimators.

Table 2. Estimation results of the Nerlovian adaptive-expectation and partial-adjustment models for teff, barley, and wheat.

\begin{tabular}{|c|c|c|c|c|c|c|}
\hline & \multicolumn{3}{|c|}{ Area Response (in hectares (ha)) } & \multicolumn{3}{|c|}{ Yield Response (in Real Birr Value) } \\
\hline & (1) & (2) & (3) & (4) & (5) & (6) \\
\hline Variables & Teff Area & Barley Area & Wheat Area & Teff Value & Barley Value & Wheat Value \\
\hline \multirow{2}{*}{$\begin{array}{l}\text { Lagged Dep. } \\
\text { Variable (ha) }\end{array}$} & $0.249^{* * *}$ & -0.099 & 0.244 * & $0.180 * * *$ & $-0.542^{* * *}$ & $-0.148 *$ \\
\hline & $(0.079)$ & $(0.398)$ & $(0.144)$ & $(0.067)$ & $(0.176)$ & $(0.082)$ \\
\hline \multirow{2}{*}{$\begin{array}{l}\text { Current teff price (real } \\
\text { price per kg (birr)) }\end{array}$} & $-4.381 * *$ & -7.701 & $6.566 *$ & $-19.463^{* * *}$ & $14.524^{* *}$ & $19.434 * *$ \\
\hline & $(2.165)$ & $(7.480)$ & $(3.950)$ & $(4.989)$ & $(5.884)$ & $(7.806)$ \\
\hline \multirow{2}{*}{$\begin{array}{l}\text { Lagged teff price (real } \\
\text { price per kg (birr)) }\end{array}$} & $5.460 * * *$ & $12.774 *$ & -4.098 & $11.386^{* * *}$ & $-6.321 *$ & -2.253 \\
\hline & $(1.860)$ & $(6.834)$ & $(3.091)$ & $(2.746)$ & $(3.355)$ & $(5.608)$ \\
\hline \multirow{2}{*}{$\begin{array}{l}\text { Current barley price } \\
\text { (real price per kg } \\
\text { (birr)) }\end{array}$} & 0.044 & $0.876^{* *}$ & 0.0289 & -0.290 & $3.015^{* * *}$ & 0.333 \\
\hline & $(0.284)$ & $(0.422)$ & $(0.270)$ & $(0.312)$ & $(0.290)$ & $(0.355)$ \\
\hline \multirow{2}{*}{$\begin{array}{l}\text { Lagged barley price } \\
\text { (real price per kg } \\
\text { (birr)) }\end{array}$} & -0.055 & $0.443^{* *}$ & 0.16 & $0.236^{* *}$ & $1.083^{* * *}$ & $0.361^{* * *}$ \\
\hline & $(0.114)$ & $(0.187)$ & $(0.122)$ & $(0.120)$ & $(0.206)$ & $(0.127)$ \\
\hline \multirow[t]{2}{*}{$\begin{array}{l}\text { Current wheat price } \\
\text { (real price per kg } \\
\text { (birr)) }\end{array}$} & -0.158 & $-0.879 *$ & -0.216 & $-1.300^{* * *}$ & $-0.516^{*}$ & $0.827^{* * *}$ \\
\hline & $(0.200)$ & $(0.467)$ & $(0.168)$ & $(0.376)$ & $(0.307)$ & $(0.243)$ \\
\hline \multirow[t]{2}{*}{$\begin{array}{l}\text { Lagged wheat price } \\
\text { (real price per kg } \\
\text { (birr)) }\end{array}$} & -0.0687 & $-0.455^{* *}$ & -0.069 & $-0.225^{*}$ & 0.041 & 0.025 \\
\hline & $(0.069)$ & $(0.179)$ & $(0.116)$ & $(0.128)$ & $(0.189)$ & $(0.192)$ \\
\hline Farm size (ha) & $\begin{array}{l}-1.512 \\
(3.056)\end{array}$ & $\begin{array}{l}10.84^{* *} \\
(4.975)\end{array}$ & $\begin{array}{l}6.204^{* *} \\
(3.136)\end{array}$ & & & \\
\hline Lagged farm size (ha) & $\begin{array}{c}-1.910 * * \\
(0.943)\end{array}$ & $\begin{array}{c}-7.780 * * \\
(3.551)\end{array}$ & $\begin{array}{c}1.1 \\
(1.253)\end{array}$ & & & \\
\hline Area of the crop (ha) & & & & $\begin{array}{c}0.248 \\
(0.365)\end{array}$ & $\begin{array}{l}-0.673^{* *} \\
(0.264)\end{array}$ & $\begin{array}{c}0.276 \\
(0.604)\end{array}$ \\
\hline \multirow[t]{2}{*}{$\begin{array}{l}\text { Lagged area of the } \\
\text { crop (ha) }\end{array}$} & & & & -0.071 & $0.611^{* *}$ & $0.941 * * *$ \\
\hline & & & & $(0.163)$ & $(0.300)$ & $(0.362)$ \\
\hline \multirow[t]{2}{*}{ Rainfall amount (mm) } & $2.755^{* * *}$ & 5.037 & $-1.790 *$ & -1.567 & -0.442 & -0.212 \\
\hline & $(0.717)$ & $(3.335)$ & $(0.994)$ & $(1.209)$ & $(0.567)$ & $(1.237)$ \\
\hline \multirow[t]{2}{*}{ Land quality index } & 0.127 & 0.652 ** & -0.155 & $1.371^{* * *}$ & $-1.657^{* * *}$ & $-2.200 * * *$ \\
\hline & $(0.238)$ & $(0.304)$ & $(0.236)$ & $(0.452)$ & $(0.264)$ & $(0.447)$ \\
\hline \multirow[t]{2}{*}{ Education dummy } & 1.335 & 10.79 & 6.334 & $18.473^{* * *}$ & -0.005 & $-10.345^{* *}$ \\
\hline & $(4.233)$ & $(8.926)$ & $(4.076)$ & $(5.340)$ & $(1.975)$ & $(4.004)$ \\
\hline Fertilizer (birr) & & & & & & $\begin{array}{l}0.389 * \\
(0.209)\end{array}$ \\
\hline Teff dummy & & $\begin{array}{c}-10.39 * * \\
(4.951)\end{array}$ & $\begin{array}{c}3.033 \\
(2.162)\end{array}$ & & $\begin{array}{c}2.660 \\
(1.666)\end{array}$ & $\begin{array}{c}13.388^{* * *} \\
(4.321)\end{array}$ \\
\hline Barley dummy & $\begin{array}{l}-0.500 \\
(1.232)\end{array}$ & & $\begin{array}{c}0.391 \\
(1.634)\end{array}$ & $\begin{array}{c}2.775 \\
(2.242)\end{array}$ & & $\begin{array}{c}-9.021^{* * * *} \\
(1.903)\end{array}$ \\
\hline
\end{tabular}


Table 2. Cont.

\begin{tabular}{|c|c|c|c|c|c|c|}
\hline & \multicolumn{3}{|c|}{ Area Response (in hectares (ha)) } & \multicolumn{3}{|c|}{ Yield Response (in Real Birr Value) } \\
\hline & (1) & (2) & (3) & (4) & (5) & (6) \\
\hline Variables & Teff Area & Barley Area & Wheat Area & Teff Value & Barley Value & Wheat Value \\
\hline Wheat dummy & $\begin{array}{l}2.642 * \\
(1.506)\end{array}$ & $\begin{array}{c}2.291 \\
(5.559)\end{array}$ & & $\begin{array}{l}-1.122 \\
(2.120)\end{array}$ & $\begin{array}{c}1.121 \\
(2.249)\end{array}$ & \\
\hline Time dummy (2006) & $\begin{array}{c}5.872 * * \\
(2.779)\end{array}$ & $\begin{array}{c}8.867 \\
(9.588)\end{array}$ & $\begin{array}{c}-9.403 * \\
(5.015)\end{array}$ & $\begin{array}{l}22.699 * * * \\
(5.912)\end{array}$ & $\begin{array}{c}-28.035^{* * *} \\
(8.961)\end{array}$ & $\begin{array}{c}-25.995^{* * *} \\
(9.719)\end{array}$ \\
\hline Constant & $\begin{array}{c}-17.47 * * * \\
(4.447)\end{array}$ & $\begin{array}{l}-29.47 * \\
(17.480)\end{array}$ & $\begin{array}{l}-2.709 \\
(5.948)\end{array}$ & & & \\
\hline $\begin{array}{l}\text { Arellano-Bond test of } \\
\text { AR(1) ( } p \text {-value) }\end{array}$ & 0.016 & 0.003 & 0.064 & 0.000 & 0.000 & 0.000 \\
\hline $\begin{array}{l}\text { Sargan test of overid. } \\
\text { restrictions ( } p \text {-value) }\end{array}$ & 0.096 & 0.353 & 0.204 & 0.515 & 0.161 & 0.151 \\
\hline $\begin{array}{l}\text { Hansen test of overid. } \\
\text { restrictions ( } p \text {-value) }\end{array}$ & 0.226 & 0.702 & 0.722 & 0.514 & 0.000 & 0.012 \\
\hline $\begin{array}{c}\text { Hansen test of } \\
\text { exogeneity of } \\
\text { instruments ( } p \text {-value) }\end{array}$ & 0.266 & 0.691 & 0.196 & 0.689 & 0.461 & 0.006 \\
\hline $\begin{array}{c}\text { Hansen test of } \\
\text { exogeneity of } \\
\text { instrument subsets } \\
(p \text {-value })\end{array}$ & 0.219 & 0.567 & 0.939 & 0.247 & 0.000 & 0.631 \\
\hline $\begin{array}{l}\text { F-test of overall model } \\
\text { fitness ( } p \text {-value) }\end{array}$ & 0.000 & 0.000 & 0.000 & 0.000 & 0.000 & 0.000 \\
\hline $\begin{array}{l}\text { Number of } \\
\text { instruments }\end{array}$ & 20 & 20 & 20 & 23 & 22 & 21 \\
\hline Number of households & 1323 & 1323 & 1323 & 1323 & 1323 & 1323 \\
\hline $\begin{array}{c}\text { Number of } \\
\text { observations }\end{array}$ & 3170 & 3170 & 3170 & 3170 & 3170 & 3170 \\
\hline
\end{tabular}

Notes: all prices were deflated using producer price indices in 1994. The Sargan test of overidentification restriction is performed to verify whether the figures are "not robust but not weakened by many instruments", whereas the Hansen test of overidentification restriction is performed to verify whether the figures are "robust" but weakened by many instruments. The Hansen test of exogeneity of instruments is reported with $p$-values. Coefficients are simultaneous two-step system GMM estimates, with the lagged dependent variable and the price variable treated as predetermined. Robust standard errors are in parentheses. The set of instruments includes the exogenous variables in vector $Z$. The difference-in-Hansen test reports the $p$-values for the validity of the additional moment restriction necessary for system GMM. The autocorrelation order one, AR(1), reports the $p$-values for the first-order autocorrelation of the first-differenced residuals. Stars *,**, and ${ }^{* * *}$ represent the $10 \%, 5 \%$, and $1 \%$ levels of significance, respectively.

The major research questions of interest were how major cereal crop supplies respond to price and nonprice factors, how the different supply responses behave across cereals, and whether these cereal supplies responded to price changes before and after 2006. The empirical applications of the cobweb supply model, in which producers' expectations regarding prices are assumed to be based on their observations of previous prices, are relevant to this analysis. An important point of departure in this study is that both the area and yield responses are measured. Table 2 reports the dynamic panel data estimator results for the area and yield responses.

Following the Nerlovian approach, I used area and yield responses to measure the supply responses to prices and nonprice factors. Based on my data, the area response appears to be a more reliable indicator of the supply response compared to the yield response for the reasons ${ }^{6}$ explained earlier. It is also implicit that the acreage responses underestimate the supply responses when farmers respond to price incentives partly through the intensive application of other inputs in a given area, which can be reflected in the yields. Therefore, the acreage and yield response functions were estimated separately and, subsequently, the supply response estimates were derived using these two responses.

6 The area decision is, to a large extent, under the control of the farmer, while the yield responses can be affected by the inputs used and the weather conditions, as evidenced by different tests (autoregressive, over-identification restrictions, exogeneity of instruments, and unobserved heterogeneity) and economic theories. 
In this case, the supply responses better reflect farmers' behaviors. Otherwise, the supply response could be biased to conceal some variations in the area and yield if they move in opposite directions.

The estimated coefficients reported in Table 2 show the elasticity of the household-level crop area planted and yield produced. Yield responses are approximated by value. The results show that almost all variables of interest in the acreage equation are statistically significant for teff, wheat, and barley. The acreage responses of major crops are affected positively by their own prices for teff and barley, and negatively by the prices of substitute crop for barley (reported in columns 1, 2, and 3). On average, if the price of a staple food crop at the household level increases by $1 \%$, the teff acreage rises by $5.46 \%$, and the barley acreage increases by $0.443 \%$. Similarly, there is also a significant yield response to the output price for the same crops. The yield response of major crops is affected positively by their own prices and negatively by the prices of substitute crops for teff and barley. If the price of a staple food crop at the household level increases on average by $1 \%$, the teff yield rises by $11.386 \%$, and the barley yield increases by $1.083 \%$. The results of estimating the Nerlovian partial-adjustment model shed new light onto the supply dynamics of major cereal crops in Ethiopian agriculture. In particular, the estimated one-year lagged-area elasticity of these crops indicates a solid influence of farmers' previous allocation decisions on current decisions of teff and wheat, which is consistent with previous findings (Zhai et al. 2019). Considering these results, I can make the following points. First, Ethiopian farmers can interpret the market signals and respond positively to increases in the real prices of staple food crops, as suggested by economic theory. Second, the results show that farmers use price information not only to decide how much acreage to allocate to the crops but also to adjust their farming intensity throughout the cropping period. Finally, teff's short-term price response coefficients are better in terms of magnitude, sign, and statistical significance than are the coefficients of barley and wheat for both area and yield responses. This is because teff is one of the major food crops consumed locally and demanded globally because of its use in gluten-free products. These findings are consistent with standard economic theory and intuition.

Additionally, in terms of the statistical significance of individual coefficients, the teff equation is consistent in terms of sign compared to the barley and wheat equations. The crop's own price plays an important role in acreage decisions for teff and barley in addition to nonprice factors. Teff can be consumed mainly alone or with wheat as a staple food. For wheat, production decision is positively influenced by its own price, unlike acreage decision. A significant volume of wheat is imported annually. Wheat is also consumed mainly in the form of bread. Barley is used to make homemade beer, which is locally known as tela, and as an input for local breweries. Thus, these crops are considered complements to or substitutes for one another. They also compete mainly for land and labor. There are significant supply responses to price increases of major crops in Ethiopia.

Moreover, the results identify potential competitor crops and complements of major cereal crops in Ethiopia. More specifically, teff is identified as a complementary crop of barley by the model, as the supply (sown area) of barley in response to the lagged price of teff is positive (and statistically significant), suggesting a complementary relationship between the sown area of barley and the teff price. Moreover, wheat is identified as a competitive crop of barley by the model, as the sown areas of barley in response to the price of wheat are negative and statistically significant, indicating a competitive relationship between the sown area of barley and the lagged wheat price. Meanwhile, the teff sown-area response is not influenced by the prices of any of these major cereal crops (barley and wheat). Similarly, in terms of yield, barley and wheat are identified as a complement and competitive crop of teff yield by the model, respectively. The produced yield of teff in response to the lagged price of barley and wheat is positive and negative, respectively, and statistically significant, indicating a complementary and competitive relationship between the produced yield of teff and the lagged barley and wheat prices, respectively. Teff is identified as a competitive crop of barley produced and statistically significant, indicating a competitive relationship between barley produced and the lagged price of teff, whereas barley is identified as a complementary crop of wheat by the model, indicating a complementary relationship between wheat produced and the lagged price of barley. 
Furthermore, the results in Table 2 suggest that the impacts of nonprice factors, such as the total farm size, rainfall, land quality, fertilizer, and education, have somewhat mixed effects. For example, rainfall has a positive effect on the teff area planted and a negative effect on the wheat area planted. The current-period teff and barley area allocations are affected negatively by the corresponding total farm sizes in the previous period. Meanwhile, the current-period barley and wheat area allocations are affected positively by the corresponding total farm size in the current period.

Finally, Table 2 reports that statistical tests concerning the differences between the pre- and post-price increase estimates provide few rejections of the equality of these estimates. The difference in statistical significance is shown in the area and yield responses of teff and wheat. There is clear evidence that the response of the teff area increased after the price increases, while the wheat area decreased. There is no clear evidence to support the notion that the response of the barley area increased significantly after the price increase. Similar patterns were observed in terms of yield responses for these crops. Among the yield responses, that of teff increased, while that of wheat and barley decreased after 2006.

Generally, area allocation among individual crops can be affected by other factors, including whether an individual farmer practices monoculture or intercropping, the farm size, the possibility of crop rotation vs. designating certain areas that are more suited to specific crops, and the proportion of area covered by perennial crops. Given all of these factors, farmers shift crops between areas based on the output price expectations and yields desired. Large farms have more space for shifting areas between crops than do small farms. Thus, the operators of small farms are likely to face more constraints on area shifting between crops in comparison to large farm operators.

\subsection{Short-Term and Long-Term Elasticities and Adjustment Coefficients of Major Crops}

As shown in Table 3, I find positive short- and long-term price elasticities for teff and barley. Table 3 reports that the acreage response elasticity of teff estimates is very high, ranging between 5.46 in the short term to 21.16 in the long term. In particular, a 1\% increase in the teff price increases-on average-teff acreage by $5.46 \%$, teff yield by $11.39 \%$, and teff supply (sum of acreage and yield) by $16.85 \%$ in the short term. Similarly, a $1 \%$ increase in the teff price increases-on average-teff acreage by $7.27 \%$, teff yield by $13.89 \%$, and teff supply (sum of acreage and yield) by $21.16 \%$ in the long term. Teff is the most consumed cereal in the country, and is consumed in the form of injera (local pancake); furthermore, it is undergoing increasing international demand due to its use in gluten-free products. Both the short-term and long-term area and yield response elasticities of barley are positive. For barley, a $1 \%$ increase in price increases-on average-barley acreage by $0.44 \%$, barley yield by $1.08 \%$, and barley supply by $1.52 \%$ in the short term. Likewise, a $1 \%$ increase in the barley price increases-on average-barley acreage by $0.40 \%$, barley yield by $0.70 \%$, and barley supply by $1.10 \%$ in the long term. This is partly explained by the growing barley demand from breweries. In contrast, the wheat area response elasticities are negative and insignificant in both the short and long term. This is partly explained by the growing wheat import by the country. Considering both the area and yield estimated coefficients, this study supports the notion that farmers respond to increasing prices to some degree through the intensive application of other inputs, such as fertilizer, in addition to extending the area planted. As expected, the long-term elasticities with respect to the lagged real prices are higher than the short-term elasticities, which is indicative of the long-term adjustment of the areas and yields under the crops. This is due to various factors that are fixed in the short term, as well as structural constraints, and because some farmers respond when they feel more certain that price changes are stable.

The adjustment coefficient measures the speed and magnitude of change between the desired and actual area (yield). The adjustment coefficient is calculated by one minus the coefficient of the lagged dependent variable. They all are above average, i.e., $\gamma>0.5$, indicating that the adjustment speed is higher. As shown in Table 3, the adjustment coefficient for the teff area is $1-0.25(=0.75)$, which is close to one, indicating that farmers adjust rapidly towards the desired teff acreage. Additionally, the adjustment coefficients for the barley and wheat areas are 1.10 and 0.76 , respectively. Thus, 
barley and wheat producers adjust towards the desired area relatively more rapidly than do those producing teff. The supply response to the price is larger in the case of teff, which is a "major" food crop in Ethiopia. This difference might be because teff production is mainly conducted for market consumption, whereas barley and wheat are mainly grown for home consumption in most of the study areas. A higher proportion of teff produced is traded compared to barley and wheat. This is partly due to teff becoming a famous food grain globally because of its use in gluten-free products. The increase in teff demand has contributed to an increase in teff acreage.

Table 3. Short-term and long-term elasticities with respect to real output prices and partial-adjustment coefficients of major crops.

\begin{tabular}{cccccccccc}
\hline Particulars & \multicolumn{3}{c}{ Teff } & \multicolumn{3}{c}{ Barley } & \multicolumn{3}{c}{ Wheat } \\
\hline & Area & Yield & Supply & Area & Yield & Supply & Area & Yield & Supply \\
\hline Short term & $5.46^{* * *}$ & $11.39^{* * *}$ & 16.85 & $0.44^{* *}$ & $1.08^{* * *}$ & 1.52 & -0.07 & 0.03 & -0.04 \\
Long term & $7.27^{* * *}$ & $13.89^{* * *}$ & 21.16 & $0.40^{* *}$ & $0.70^{* * *}$ & 1.10 & -0.10 & 0.02 & -0.08 \\
Adjustment & $0^{*} 5^{* * *}$ & $0.82^{* * *}$ & 1.57 & $1.10^{* * *}$ & $1.54^{* * *}$ & 2.64 & $0.76^{* * *}$ & $1.15^{* * *}$ & 1.90 \\
\hline
\end{tabular}

Source: author's calculations. ${ }^{* * *}$ significant at the $1 \%$ level; ${ }^{* *}$ significant at the $5 \%$ level.

Alemu et al. (2003) estimated the supply response of agricultural output to the prices of teff and wheat in Ethiopia and reported the short-term elasticities of 0.14 and 0.15 for teff and wheat, respectively, and the long-term elasticity of 0.28 for both crops using time-series data from 1966 to 1994. Abrar and Morrissey (2006) estimated the supply response of agricultural output to prices in Ethiopia and reported short-term elasticities of $0.07,-0.02$ and 0.27 for teff, wheat, and barley, respectively, using panel data from Northern Ethiopia during 1994 to 2000. Abrar et al. (2004b) also estimated the supply response of agricultural output to prices in Ethiopia and reported short-term elasticities of 0.28 , 0.22, and 0.04 for teff, wheat, and barley, respectively, during 1994 to 1997. Dercon and Ayalew (1995) studied the export supply response of coffee to the export price and reported the short-term elasticity of 0.17 and the long-term elasticity of 0.27 .

In sub-Saharan Africa (SSA), Magrini et al. (2018) estimated the supply responses of main staple food crops and reported acreage, production, and yield response ranges from a 0.08 acreage response using the farm gate price to a 0.63 production response using wholesale price proxies in SSA over the period 2005-2013 based on country panel data. The effects of prices on supply responses in Africa have been estimated by considering agricultural aggregates (Bond 1983; McKay et al. 1999; Thiele 2003). Bond (1983) estimated the individual crop-level and aggregate supply responses of the agricultural output to the prices of various crops in nine SSA countries. He reported individual crop price elasticities ranging from 0.02 to 0.87 in the short term and from 0.07 to 1.81 in the long term from 1962 to 1981 . McKay et al. (1999) studied the aggregate supply response in Tanzanian agriculture and estimated that the long-term elasticity of the aggregate food crop output to the relative prices was almost unity, while the short-term supply responses were estimated at 0.35 for aggregate food crops and all (food and export) crops. Thiele (2003) estimated that border price supply elasticities tend to lie between 0.20 and 0.50 in SSA countries covering the period 1965-1999. In addition, Leaver (2004) used an adapted Nerlovian model to study the price elasticity of the supply for tobacco output in Zimbabwe from 1938 to 2000 and reported a short-term elasticity of 0.34 and a long-term elasticity of 0.81 , suggesting that tobacco farmers are highly responsive to output price changes. Rahji and Adewumi (2008) obtained a higher long-term price elasticity of rice production in Nigeria (1.58) between 1960 and 2004, further verifying the crucial role of the supply response in agricultural markets in developing countries.

Imai et al. (2011) studied the extent to which the production of different agricultural commodities, namely, maize, wheat, rice, fruit, vegetables, and oilseeds, responds to price changes in 10 Asian countries and reported a short-term elasticity ranging from 0.25 to 0.31 for these commodities. Zhai et al. (2019) used the system GMM estimator using provincial-level panel data (1997-2016) and reported partial adjustments (i.e., At-1 and Pt-1) of 0.21 and 0.87 , respectively, for the green fodder supply in China. Similarly, Brockhaus et al. (2015) presented new evidence using provincial panel data 
over the period 1995-2012 for rice, wheat, and corn supply responses in China. They used the system GMM estimator and reported price elasticities ranging from 0.16 (rice) to 0.34 (wheat). Mythili (2012) studied the supply responses of rice, wheat, maize, grams, groundnuts, rapeseed, mustard, sugarcane, and cotton using state-level panel data over the period of 1970-2000 in India. He used the GMM estimator and reported price elasticities ranging from 0.084 (rice) to 0.338 (grams) in the short term and from 0.408 (rice) to 1.15 (grams) in the long term in terms of the acreage response, whereas the elasticities ranged from 0.071 (rice) to 0.321 (maize) in the short term and from 0.085 (grams) to 0.393 (maize) in the long term in terms of the yield response. Surekha (2005) also reported a similar result for rice, indicating that farmers in India are responsive to price changes. Rahman (2007) estimated the price elasticity of Bangladesh tea production to be 1.10. Another study by Nerlove and Addison (1958) reported a short-term elasticity of 0.02 and a long-term elasticity of 4.7 for spinach in the USA. Generally, cropping decisions in India are affected by agro-climatic conditions, land characteristics, and farmers' knowledge about the crop, in addition to the price variable (Gulati and Kelly 1999).

In the short term, land availability cannot be improved without huge investments. Moreover, delays in the supplies of production capital contribute to delayed supply responses, and labor availability cannot change except through increasing populations or relocation among sectors or regions. Long-term supply responses require labor and capital increases, which take place over a relatively long time, as well as farmers' decisions to invest and adopt new technology that enables them to increase output. In contrast, fertilizers, improved seeds, and pesticides are the only variable inputs whose application can be adjusted in the short term to policy incentives. However, the applications of these inputs to Ethiopian agriculture are low. The application of improved seeds accounted for less than $1 \%$ of the total seeds, less than $47 \%$ of the respondents use fertilizer, less than $5 \%$ of the total area was irrigated, and there was almost no usage of pesticides or insecticides.

\section{Conclusions and Policy Implications}

My results are quite similar to those obtained from the supply responses of agricultural outputs to price incentives and nonprice incentives from Ethiopia and other countries, although they all used different functional forms, estimation methods, time spans and data types (cross-sectional, time-series, or panel data), and region- and country-specific factors related to technology, the economic structure, and macro constraints. My study has strengthened the findings of previous studies, namely, by indicating that farmers are quite responsive to price changes, particularly in the longer term (Food and Agriculture Organization 2016). This is a good start for making market-based policies work, even in rural Africa (Kumbhakar and Heshmati 1995; Kumbhakar and Hjalmarsson 1995). This paper sought to establish some general conclusions on supply responsiveness by taking these data and methodological limitations into account. My trustworthiness is increased, as I used data from a large sample and employ recent econometric estimation methods that, to some extent, have not been used in such settings before in Ethiopia.

This study measured the dynamic supply responses of major cereal crops to price incentives and nonprice factors in Ethiopia. Through the Nerlovian expectation approach, in conjunction with a dynamic panel data model, the system-generalized method of moments was used for the estimation. Price incentives and nonprice factors such as rainfall, adult education, land quality, fertilizer, and farm size affect the aggregate output supply of major cereal crops in the country. The study also investigated the effects of price increases on the supply response before and after price increases since 2006. Estimates of the agricultural supply relative to the expected price exhibited large variations across crops and time. There are considerable supply responses to increases in the prices of major cereal crops in Ethiopia. The area and yield responses of major cereal crops are responsive to price incentives.

The planted area and produced yield are quite responsive to price incentives and nonprice factors for major cereal crops in Ethiopia, based on the estimated short-term and long-term elasticities. Moreover, the long-term estimates are much larger than the short-term values for teff. The agricultural output responses to price incentives and nonprice variables are lower in the short term because most 
factors affecting agricultural production are fixed in the short term. The elasticities for a household-level crop area planted and yield produced with respect to the crop price are positive and statistically significant for both teff and barley but not for wheat. The cross-price elasticities are statistically significant for barley and wheat but not for teff, indicating that teff is a basic food in the country. More specifically, teff is identified as a complementary crop of barley by the model, as the sown area of barley in response to the lagged price of teff is positive. Moreover, wheat is identified as a competitive crop of barley by the model, as the sown area of barley in response to the price of wheat is negative. Meanwhile, the teff sown-area response is not influenced by the prices of any of these major cereal crops (barley and wheat). In addition, the yield responses to lagged-price elasticities are positive and statistically significant for teff and barley. Furthermore, current price elasticity is positive and significant for wheat yield response. Hence, the supply responses evaluated alongside the acreage and yield responses are responsive to price increases. Overall, the coefficients associated with area responses more consistently reveal the expected signs compared to those of the yield responses. This finding is consistent with standard economic theory and intuition in that area decisions are less sensitive to weather changes compared to yields and are under the control of the householders' decisions. Moreover, there is a statistically significant supply response difference before and after the price increases from 2006 in the case of teff and wheat areas, as well as teff, barley, and wheat yields. For example, teff is becoming the most demanded crop, hence, its area has increased; in contrast, wheat is imported by the government, and its area decreased after 2006. For barley, there has been an increase in the yield, and it is clearly evidenced by the statistics, given that barley is becoming a commercial crop.

This study supports the notion that major cereal food price changes may induce the production of a large supply of food grains. This study implies that the expansions of both teff and barley areas are possible in the country. This is important because teff is one of the major food crops consumed locally (by approximately 110 million people of the country) and demanded globally because of its use in gluten-free products, whereas barley is another food crop demanded because of its use in low glycemic index products and is becoming a commercial crop with the expansion of the domestic brewery industry. However, the wheat area is least affected by own price. This is partly explained by the growing volume of wheat imports by the country. These findings also imply that the agriculture sector in Ethiopia is responsive to output price increases, which was a common phenomenon in 2007 and 2008 worldwide. Thus, I claim that the growth record of Ethiopian agriculture over the last decade is partly explained by the increased agricultural prices, which were driven by local, regional, and international factors. This relationship implies that promoting access to markets by allowing farmers to receive higher prices enhances the income of smallholders, increases the national food supply, and narrows inequity.

Ethiopian (developing countries) agriculture needs improvement in terms of input supply (such as improved seeds, fertilizer, irrigation, infrastructure, and farm management) to enhance the welfare of the farmers and society as a whole using a mixture of markets and government policy interventions. Competitive markets enable more efficient allocation of scarce resources and allow the supply and demand to set prices. Markets also enhance cost-effective and flexible resource allocation. Unlike many developing countries, most resources in modern economies are allocated via markets rather than by governments. The main role of the government ought to be to establish the rules and institutions needed for markets to work, not to control the price signals from markets.

However, there are occasions when markets fail, which could justify government interventions to correct these market failures. The reasons for such failure include information asymmetries, noncompetitive markets, principal-agent problems, and externalities. Effective markets require government intervention in the establishment and operation of a secure property rights system, the provision of information, macroeconomic stability, endowment redistribution, and support for social capital. Government should intervene via subsidies, quotas, restrictions, expenditures on research and development, infrastructure (irrigation, transport, and communication), property ownership 
rights, education and extension services, risk coping, and management strategies, and the adoption of new technology to enhance production in addition to price incentives.

Furthermore, the government should enhance economic growth and development in the country to improve the purchasing power of food buyers. The government should also provide subsidies for smallholder farmers to allow them to use improved technologies, train farmers on how to use new technologies, lift export bans, place higher tariffs on food imports to enhance local production until domestic markets work better, and stabilize the prices so that smallholder farmers can easily make area allocation decisions for specific crops. Better agricultural trade policies are required to encourage more effective supply responses. The research and development of modern technologies to improve production and productivity in Ethiopia should also strengthen the supply response of agriculture, in addition to price incentives. A fine-tuned balance between government interventions and market solutions is important, in addition to improving farmers' agronomic practices, for increasing agricultural production and, thus, farmers' and consumers' welfare.

Funding: The author is grateful for the financial assistance received from the Norwegian State Educational Loan Fund.

Acknowledgments: The author would like to thank Addis Ababa University (AAU), the Centre for the Study of Africa Economics (CSAE) at Oxford, and the International Food Policy Research Institute (IFPRI) for Ethiopia Rural Household Survey (ERHS) data, and the Ethiopian National Meteorological Service Agency for rainfall data used in this article. The constructive and helpful comments received from Eirik Romstad, Menale Kassie, Gudbrand Lien, Mette Wik, Stein T. Holden, Daniel Muluwork and Getaw Tadesse at different stages of preparing this article are extremely appreciated.

Conflicts of Interest: The author declares no conflict of interest.

\section{Appendix A. Derivations of the Nerlovian Expectation and Adjustment Coefficients}

By imposing a restriction indicating that $\beta=1$ and substituting Equations (2) and (3) into Equation (1), a reduced form equation is derived as follows:

$$
\begin{aligned}
& \mathrm{P}_{\mathrm{t}}^{\mathrm{e}}=\mathrm{P}_{\mathrm{t}-1}^{\mathrm{e}}+\beta \mathrm{P}_{\mathrm{t}-1}-\beta \mathrm{P}_{\mathrm{t}-1}^{\mathrm{e}} \\
& \mathrm{A}_{\mathrm{t}}=\mathrm{A}_{\mathrm{t}-1}+\gamma \mathrm{A}_{\mathrm{t}}^{\mathrm{d}}-\gamma \mathrm{A}_{\mathrm{t}-1}
\end{aligned}
$$

Substitute Equation (A1) into Equation (1), where $\beta=1$ :

$$
A_{t}^{d}=\alpha_{0}+\alpha_{1} p_{t-1}^{e}+\alpha_{1} P_{t-1}-\alpha_{1} p_{t-1}^{e}+\alpha_{2} Z_{t}+v_{t} A_{t}^{d}=\alpha_{0}+\alpha_{1} P_{t-1}+\alpha_{2} Z_{t}+u_{t}
$$

Substitute Equation (A3) into Equation (A2):

$$
\begin{gathered}
A_{t}=A_{t-1}+\gamma\left(\alpha_{0}+\alpha_{1} P_{t-1}+\alpha_{2} Z_{t}+u_{t}\right)-\gamma A_{t-1} \\
A_{t}=A_{t-1}+\gamma \alpha_{0}+\gamma \alpha_{1} P_{t-1}+\gamma \alpha_{2} Z_{t}+\gamma u_{t}-\gamma A_{t-1}
\end{gathered}
$$

Collect like terms:

$$
A_{t}=\gamma \alpha_{0}+\gamma \alpha_{1} P_{t-1}+\gamma \alpha_{2} Z_{t}+(1-\gamma) A_{t-1}+\gamma v_{t}
$$

The equation becomes:

$$
A_{t}=a_{0}+a_{1} P_{t-1}+a_{2} Z_{t}+a_{3} A_{t-1}+v_{t}
$$


Because $\mathrm{A}_{\mathrm{t}}^{\mathrm{d}}$ and $\mathrm{P}_{\mathrm{t}}^{\mathrm{e}}$ are unobservable, they are eliminated from the system. This elimination of unobserved variables leads to the reduced form, from which the key parameters can be retrieved. Similarly, the Nerlovian model can also be described in terms of the output as:

$$
\begin{gathered}
\mathrm{Y}_{\mathrm{t}}^{\mathrm{d}}=\alpha_{0}+\alpha_{1} \mathrm{p}_{\mathrm{t}}^{\mathrm{e}}+\alpha_{2} \mathrm{Z}_{\mathrm{t}}+\mathrm{v}_{\mathrm{t}} \\
\mathrm{P}_{\mathrm{t}}^{\mathrm{e}}-\mathrm{P}_{\mathrm{t}-1}^{\mathrm{e}}=\beta\left(\mathrm{P}_{\mathrm{t}-1}-\mathrm{P}_{\mathrm{t}-1}^{\mathrm{e}}\right), 0 \leq \beta \leq 1 \\
\mathrm{Y}_{\mathrm{t}}-\mathrm{Y}_{\mathrm{t}-1}=\gamma\left(\mathrm{Y}_{\mathrm{t}}^{\mathrm{d}}-\mathrm{Y}_{\mathrm{t}-1}\right), 0 \leq \gamma \leq 1
\end{gathered}
$$

where $Y_{t}^{d}$ is the desired level of output; $Y_{t}$ is the actual level of output; $p_{t}^{e}$ is a vector of the expected level of prices for period $t ; Z_{t}$ represents the nonprice factors; $\alpha_{i}$ are parameters; and $v_{t}$ accounts for unobserved random factors with zero expected value. Equation (A7) states that the desired level of output depends on the expected price level and other nonprice factors. The Nerlovian model is developed to take two dynamic processes into account: adaptive expectations and partial adjustments. Desired levels of outputs cannot be observed by farmers due to latency; thus, Nerlove postulates the hypothesis known as partial adjustment (Equation $(\mathrm{A} 8 \mathrm{~b})$ ), where $\gamma$ is the coefficient of adjustment, $\left(Y_{t}-Y_{t-1}\right)$ is the actual change in output, and $\left(Y_{t}^{d}-Y_{t-1}\right)$ is the desired change in output. Equation (A9a) indicates that the actual change in output at any given time $t$ is some fraction $\gamma$ of the desired change for the period. If $\gamma=1$, the actual output is equal to the desired output; that is, the actual output adjusts to the desired output instantaneously. However, if $\gamma=0$, there is no change since the actual output at time $t$ is the same as that observed in the previous period. Generally, $\gamma$ lies between these extreme values since adjustment to the desired output is likely to be constrained by policy and natural lags.

In the Nerlove model, Equation (A8b) states that for each period, the farmers revise the price that they expect to prevail in the coming period to correct the mistakes they made in predicting the price during this period. It shows how price expectations can be described based on differences between actual and past prices, where $\mathrm{p}_{\mathrm{t}}^{\mathrm{e}}$ is the expected price for period $\mathrm{t} ; \mathrm{P}_{\mathrm{t}-1}$ is the price that prevails when decision making for production in period $t$ occurs; and $\beta$ is the adaptive-expectation coefficient. This shows that expectations are revised during each period by a fraction $\beta$ from the gap between the current value of a price and the previous expected value. Thus, expectations about the price level are revised by farmers by a fraction $\beta$ due to policy inconsistencies that affect the price level observed in the current period and the anticipated value in the previous period. If $\beta=1$, expectations are realized immediately and fully, that is, during the same period. If, on the other hand, $\beta=0$, expectations are static; that is, the conditions prevailing today will be maintained in all subsequent periods. However, expectations are seldom fully realized, and there is usually a gap between the actual and expected level of prices because of constraints from public policies and nonpolicy variables.

To use the Nerlovian model for estimation, it is necessary to transform Equations (A7)-(A8b) into their reduced forms. In the reduced form, the partial-adjustment variable $Y_{t}^{d}$ is associated with the desired output and the adaptive-expectation variable $\mathrm{P}_{\mathrm{t}}^{\mathrm{e}}$. Adaptive price expectations can be transformed into distributed lag structures in the form of the past level of output and the previously expected price level. This is consistent with the Nerlovian model, which is based on price expectations and output adjustments. The process necessary to arrive at the reduced form equation is shown below. Taking the two constants in these equations, $\beta$ and $\gamma$, by imposing a restriction that $\beta=1$ and substituting Equations (A8a) and (A9a) into Equation (A7), a reduced form of the equation is derived as follows:

$$
\begin{aligned}
& \mathrm{P}_{\mathrm{t}}^{\mathrm{e}}=\mathrm{P}_{\mathrm{t}-1}^{\mathrm{e}}+\beta \mathrm{P}_{\mathrm{t}-1}-\beta \mathrm{P}_{\mathrm{t}-1}^{\mathrm{e}} \\
& \mathrm{Y}_{\mathrm{t}}=\mathrm{Y}_{\mathrm{t}-1}+\gamma \mathrm{Y}_{\mathrm{t}}^{\mathrm{d}}-\gamma \mathrm{Y}_{\mathrm{t}-1}
\end{aligned}
$$


Substitute Equation (A9a) into Equation (A7) where $\beta=1$ :

$$
\mathrm{Y}_{\mathrm{t}}^{\mathrm{d}}=\alpha_{0}+\alpha_{1} \mathrm{p}_{\mathrm{t}-1}^{\mathrm{e}}+\alpha_{1} \mathrm{P}_{\mathrm{t}-1}-\alpha_{1} \mathrm{p}_{\mathrm{t}-1}^{\mathrm{e}}+\alpha_{2} \mathrm{Z}_{\mathrm{t}}+\mathrm{v}_{\mathrm{t}} \mathrm{Y}_{\mathrm{t}}^{\mathrm{d}}=\alpha_{0}+\alpha_{1} \mathrm{P}_{\mathrm{t}-1}+\alpha_{2} \mathrm{Z}_{\mathrm{t}}+\mathrm{v}_{\mathrm{t}}
$$

Substitute Equation (A10) into Equation (A9b):

$$
\begin{gathered}
Y_{t}=Y_{t-1}+\gamma\left(\alpha_{0}+\alpha_{1} P_{t-1}+\alpha_{2} Z_{t}+u_{t}\right)-\gamma Y_{t-1} \\
Y_{t}=Y_{t-1}+\gamma \alpha_{0}+\gamma \alpha_{1} P_{t-1}+\gamma \alpha_{2} Z_{t}+\gamma u_{t}-\gamma Y_{t-1}
\end{gathered}
$$

Collect like terms:

$$
\mathrm{Y}_{\mathrm{t}}=\gamma \alpha_{0}+\gamma \alpha_{1} \mathrm{P}_{\mathrm{t}-1}+\gamma \alpha_{2} \mathrm{Z}_{\mathrm{t}}+(1-\gamma) \mathrm{Y}_{\mathrm{t}-1}+\gamma \mathrm{v}_{\mathrm{t}}
$$

The equation becomes:

$$
Y_{t}=a_{0}+a_{1} P_{t-1}+a_{2} Z_{t}+a_{3} Y_{t-1}+v_{t}
$$

where

$$
\mathrm{a}_{0}=\gamma \alpha_{0}, \mathrm{a}_{1}=\gamma \alpha_{1}, \mathrm{a}_{2}=\gamma \alpha_{2}, \mathrm{a}_{3}=1-\gamma, \mathrm{v}_{\mathrm{t}}=\gamma \mathrm{v}_{\mathrm{t}}
$$

Hence,

$$
\begin{gathered}
\mathrm{a}_{3}=1-\gamma, \therefore \gamma=1-\mathrm{a}_{3}, \mathrm{a}_{0}=\gamma \alpha_{0}, \mathrm{a}_{0}=\left(1-\mathrm{a}_{3}\right) \alpha_{0}, \therefore \alpha_{0}=\frac{\mathrm{a}_{0}}{1-\mathrm{a}_{3}} \\
\mathrm{a}_{1}=\gamma \alpha_{1}, \mathrm{a}_{1}=\left(1-\mathrm{a}_{3}\right) \alpha_{1}, \therefore \alpha_{1}=\frac{\mathrm{a}_{1}}{1-\mathrm{a}_{3}}, \mathrm{a}_{2}=\left(1-\mathrm{a}_{3}\right) \alpha_{2}, \therefore \alpha_{2}=\frac{\mathrm{a}_{2}}{1-\mathrm{a}_{3}}
\end{gathered}
$$

The $a_{i}$ parameters are the short-term elasticities, while $\alpha_{i}$ are the long-term elasticities. Note that $\left(1-a_{3}\right)$ is the coefficient of partial adjustment (acreage or yield).

\section{References}

Abebe, H. Gabrie. 1998. The Supply Responsiveness of Peasant Agriculture in Ethiopia: Some Macroeconomic Results from Cereals Production. Ethiopian Journal of Economics 7: 1-23.

Abrar, Suleiman, Oliver Morrissey, and Tony Rayner. 2004a. Aggregate Agricultural Supply Response in Ethiopia: A Farm-Level Analysis. Journal of International Development 16: 605-20. [CrossRef]

Abrar, Suleiman, Oliver Morrissey, and Tony Rayner. 2004b. Crop-Level Supply Response by Agro-Climatic Region in Ethiopia. Journal of Agricultural Economics 55: 289-311. [CrossRef]

Abrar, Suleiman, and Oliver Morrissey. 2006. Supply Response in Ethiopia: Accounting for Technical Inefficiency. Agricultural Economics 35: 303-17. [CrossRef]

African Development Bank Group. 2016. Federal Democratic Republic of Ethiopia Country Strategy Paper 2016-2020. Abidjan: AfDB.

Alem, Braha. 1996. Trade Liberalization and External Balance in Ethiopia: The Question of Sustainability. In Adjustments in Ethiopia: Lessons for the Road Ahead. Edited by Taddess Abadi and Tekie Alemu. Addis Ababa: Ethiopian Economic Association.

Alemu, Zerihun G., K. Oosterhuizen, and Herman van Schalkwyk. 2003. Grain-Supply Response in Ethiopia: An Error-Correction Approach. Agrekon 42: 389-404. [CrossRef]

Ampadu-Ameyaw, Richard, and Dadson Awunyo-Vitor. 2014. Effect of Price and Non-price Incentives on Production and Marketable Surplus of Food Crops Supply in Ghana. Asian Journal of Agricultural Extension, Economics \& Sociology 3: 666-79.

Anderson, Kym, and William A. Masters. 2007. Distortions to Agricultural Incentives in Africa. Washington, DC: World Bank.

Arellano, Manuel, and Stephen Bond. 1991. Some Tests of Specification for Panel Data: Monte Carlo Evidence and an Application to Employment Equations. The Review of Economic Studies 58: 277-97. [CrossRef] 
Arellano, Manuel, and Olympia Bover. 1995. Another Look at the Instrumental Variable Estimation of Error-Components Models. Journal of Econometrics 68: 29-51. [CrossRef]

Askari, Hossein, and J. Thomas Cummings. 1977. Estimating Agricultural Supply Response with the Nerlove Model: A Survey. International Economic Review 18: 257-92. [CrossRef]

Awlachew, Seleshi B., Teklu Erkossa, and Regassa Namara. 2010. Irrigation Potential in Ethiopia-Constraints and Opportunities for Enhancing the System. Colombo: International Water Management Institute.

Baltagi, Badi. 2008. Econometric Analysis of Panel Data. New York: John Wiley \& Sons.

Bellemare, Marc F., Christopher B. Barrett, and David R. Just. 2013. The Welfare Impacts of Commodity Price Volatility: Evidence from Rural Ethiopia. American Journal of Agricultural Economics 95: 877-99. [CrossRef]

Blundell, Richard, and Stephen Bond. 1998. Initial Conditions and Moment Restrictions in Dynamic Panel Data Models. Journal of Econometrics 87: 115-43. [CrossRef]

Bond, Marian E. 1983. Agricultural Responses to Prices in Sub-Saharan African Countries (RÃ@)actions du secteur agricole aux prix en Afrique au sud du Sahara) (Reacciones de la agricultura ante los precios en los paÃses del Africa al sur del Sahara). IMF Staff Papers 30: 703-26. [CrossRef]

Braulke, Michael. 1982. A Note on the Nerlove Model of Agricultural Supply Response. International Economic Review 23: 241-44. [CrossRef]

Brockhaus, Jan, Jikun Huang, Jiliang Hu, Matthias Kalkuhl, Joachim von Braun, and Guolei Yang. 2015. Rice, Wheat, and Corn Supply Response in China. San Francisco: Agricultural and Applied Economics Association.

Central Statistical Agency. 2014. Federal Democratic Republic of Ethiopia, 2009-2014 Years. Statistical Abstracts and Statistical Bulletins. Addis Ababa: CSA.

Coelli, Timothy J., D. S. Prasada Rao, Christopher J. O’Donnell, and G. Edward Battese. 2005. An Introduction to Efficiency and Productivity Analysis. Berlin: Springer.

Colman, David. 1983. A Review of the Arts of Supply Response Analysis. Review of Marketing and Agricultural Economics 51: 201-30.

Dercon, Stefan, and Lulseged Ayalew. 1995. Smuggling and Supply Response: Coffee in Ethiopia. World Development 23: 1795-813. [CrossRef]

Dercon, Stefan, and John Hoddinott. 2004. The Ethiopian Rural Household Surveys: Introduction. Washington, DC: International Food Policy Research Institute.

Di Marcantonio, Federica, Cristian Morales-Opazo, Jesus Barreiro-Hurle, and Mulat Demeke. 2014. Determinants of Food Production in Sub Saharan Africa: The Impact of Policy, Market Access and Governance. In 2014 International Congress. Ljubljana: European Association of Agricultural Economists, pp. 26-29.

Diebold, Francis X., and Russell L. Lamb. 1997. Why are Estimates of Agricultural Supply Response so Variable? Journal of Econometrics 76: 357-73. [CrossRef]

Durevall, Dick, Josef L. Loening, and Yohannes Ayalew Birru. 2013. Inflation Dynamics and Food Prices in Ethiopia. Journal of Development Economics 104: 89-106. [CrossRef]

Ezekiel, Mordecai. 1938. The Cobweb Theorem. The Quarterly Journal of Economics 52: 255-80. [CrossRef]

Food and Agriculture Organization. 2016. Federal Democratic Republic of Ethiopia: Country Programming Framework-CPF, 2016-2020. Rome: FAO.

Gulati, Ashok, and Tim Kelly. 1999. Trade Liberalization and Indian Agriculture: Cropping Pattern Changes and Efficiency Gains in Semi-Arid Tropics. New York: Oxford University Press.

Haile, Mekbib G., Matthias Kalkuhl, and Muhammed A. Usman. 2015. Market Information and Smallholder Farmer Price Expectations. African Journal of Agricultural and Resource Economics 10: 297-311.

Headey, Derek D. 2016. Food Prices and Poverty. Washington, DC: The World Bank.

Holtz-Eakin, Douglas, Whitney Newey, and Harvey S. Rosen. 1988. Estimating Vector Autoregressions with Panel Data. Econometrica 56: 1371-95. [CrossRef]

Imai, Katsushi S., Raghav Gaiha, and Ganesh Thapa. 2011. Supply Response to Changes in Agricultural Commodity Prices in Asian Countries. Journal of Asian Economics 22: 61-75. [CrossRef]

Jaunky, Vishal C. 2013. Democracy and Economic Growth in Sub-Saharan Africa: A Panel Data Approach. Empirical Economics 45: 987-1008. [CrossRef]

Just, Richard E. 1993. Discovering Production and Supply Relationships: Present Status and Future Opportunities. Review of Marketing and Agricultural Economics 61: 11-40. 
Khan, Sufyan U., Muhammad A. Faisal, Zahoor Ul Haq, Shah Fahad, Ghaffar Ali, Arshad A. Khan, and Imran Khan. 2019. Supply Response of Rice Using Time Series Data: Lessons from Khyber Pakhtunkhwa Province, Pakistan. Journal of the Saudi Society of Agricultural Sciences 18: 458-61. [CrossRef]

Kumbhakar, Subal C., and Almas Heshmati. 1995. Efficiency Measurement in Swedish Dairy Farms: An Application of Rotating Panel Data, 1976-88. American Journal of Agricultural Economics 77: 660-74. [CrossRef]

Kumbhakar, Subal C., and Lennart Hjalmarsson. 1995. Labour-Use Efficiency in Swedish Social Insurance Offices. Journal of Applied Econometrics 10: 33-47. [CrossRef]

Leaver, Rosemary. 2004. Measuring the Supply Response Function of Tobacco in Zimbabwe. Agrekon 43: 113-31. [CrossRef]

Magrini, Emiliano, Jean Balié, and Cristian Morales-Opazo. 2017. Cereal Price Shocks and Volatility in Sub-Saharan Africa: What Really Matters for Farmers' Welfare? Agricultural Economics 48: 719-29. [CrossRef]

Magrini, Emiliano, Jean Balié, and Cristian Morales-Opazo. 2018. Price Signals and Supply Responses for Staple Food Crops in Sub-Saharan Africa. Applied Economic Perspectives and Policy 40: 276-96. [CrossRef]

McKay, Andrew, Oliver Morrissey, and Charlotte Vaillant. 1999. Aggregate Supply Response in Tanzanian Agriculture. The Journal of International Trade E Economic Development 8: 107-23.

Minot, Nicholas W. 2010. Transmission of World Food Price Changes to Markets in Sub-Saharan Africa. Washington: International Food Policy Research Institute.

Minot, Nicholas W. 2014. Food Price Volatility in Sub-Saharan Africa: Has it Really Increased? Food Policy 45: 45-56. [CrossRef]

Muth, John F. 1961. Rational Expectations and the Theory of Price Movements. Econometrica 29: 315-35. [CrossRef] Mythili, Gurumurthy. 2012. Acreage and Yield Response for Major Crops in the Pre-and Post-Reform Periods in India: A Dynamic Panel Data Approach. Mumbai: Indira Gandhi Institute of Development Research.

Nakelse, Tebila, Timothy J. Dalton, Nathan P. Hendricks, and Manzamasso Hodjo. 2018. Are Smallholder Farmers Better or Worse off from an Increase in the International Price of Cereals? Food Policy 79: 213-23. [CrossRef]

National Bank of Ethiopia. 2019. Annual Report 2018/2019. Addis Ababa: National Bank of Ethiopia.

National Bank of Ethiopia. 2015. Daily Exchange Rate. Available online: https://nbebank.com/commercial-banksexchange-rate/ (accessed on 17 April 2015).

Nerlove, Marc. 1956. Estimates of the Elasticities of Supply of Selected Agricultural Commodities. Journal of Farm Economics 38: 496-509. [CrossRef]

Nerlove, Marc. 1958. The Dynamics of Supply: Estimation of Farmer's Response to Price. Baltimore: The Johns Hopkins Press.

Nerlove, Marc, and William Addison. 1958. Statistical Estimation of Long-Run Elasticities of Supply and Demand. Journal of Farm Economics 40: 861-80. [CrossRef]

Nerlove, Marc. 1979. The Dynamics of Supply: Retrospect and Prospect. American Journal of Agricultural Economics 61: 874-88. [CrossRef]

Nickell, Stephen. 1981. Biases in Dynamic Models with Fixed Effects. Econometrica 49: 1417-26. [CrossRef]

NMSAE. 2014. Mean Annual Rainfall Distribution of Ethiopia. Addis Ababa: National Meteorological Service Agency of Ethiopia (NMSAE).

OECD, and Food and Agriculture Organization of the United Nations. 2016. OECD-FAO Agricultural Outlook 2016-2025. Paris: OECD.

Ogundari, Kolawole. 2018. Maize Supply Response to Price and Nonprice Determinants in Nigeria: Bounds Testing Approach. International Transactions in Operational Research 25: 1537-51. [CrossRef]

Rahji, M. A., and Matthew O. Adewumi. 2008. Market Supply Response and Demand for Local Rice in Nigeria: Implications for Self-Sufficiency Policy. Journal of Central European Agriculture 9: 567-73.

Rahman, Mohammad L. 2007. Impact of Price and Other Factors on Tea in Bangladesh: Sources of Variation and Disparity over Division. BRAC University Journal 4: 9-11.

Rashid, Shahidur. 2010. Staple Food Price in Ethiopia. Prepared for the COMESA Policy Seminar on Variation in Staple Food Prices: Causes, Consequence, and Policy Options, Maputo, Mozambique, 25-26 January 2010 Under the African Agricultural Marketing Project (AAMP). Addis Ababa: The Federal Democratic Republic of Ethiopia.

Roodman, David. 2009. How to do Xtabond2: An Introduction to Difference and System GMM in Stata. The Stata Journal 9: 86-136. [CrossRef]

Sadoulet, Elisabeth, and Alain de Janvry. 1995. Quantitative Development Policy Analysis. Baltimore: Johns Hopkins University Press. 
Shonkwiler, John S., and Suzanne Hinckley. 1985. A Generalized Supply Response/Factor Demand Model and its Application to the Feeder Cattle Market. Western Journal of Agricultural Economics 10: 245-53.

Singh, Inderjit, Lyn Squire, and John Strauss. 1986. Agricultural Household Models: Extensions, Applications, and Policy. Baltimore: Johns Hopkins University Press.

StataCorp. 2013. Stata Statistical Software: Release 13. College Station: StataCorp LP.

Surekha, K. B. Rao. 2005. Modeling Nonlinear Autoregressive Distributed Lag Models: A New Approach. Journal of Quantitative Economics 3: 101-14. [CrossRef]

Taffesse, Alemayehu S., Paul Dorosh, and Sinafikeh Asrat. 2012. Crop Production in Ethiopia: Regional Patterns and Trends. In Food and Agriculture in Ethiopia: Progress and Policy Challenges. Edited by Paul Dorosh and Shahidur Rashid. Philadelphia: University of Pennsylvania Press, pp. 53-83.

Talukder, Byomkesh, and Alison Blay-Palmer. 2017. Comparison of Methods to Assess Agricultural Sustainability. In Sustainable Agriculture Reviews. Sustainable Agriculture Reviews. Edited by Eric Lichtfouse. Cham: Springer International Publishing, pp. 149-68.

Tenaye, Anbes. 2020a. Sources of Productivity Growth in Ethiopian Agriculture. African Journal of Agricultural Research 15: 19-32.

Tenaye, Anbes. 2020b. Technical Efficiency of Smallholder Agriculture in Developing Countries: The Case of Ethiopia. Economies 8: 34. [CrossRef]

Tenaye, Anbes, and Endrias Geta. 2009. Analysis of Vulnerability and Determinants of Enset Production in Wolaita, Southern Ethiopia. Acta Horticulturae 806: 663-68. [CrossRef]

Thiele, Rainer. 2003. Price Incentives, Non-price Factors and Agricultural Production in Sub-Saharan Africa: A Cointegration Analysis. African Development Review 15: 425-38. [CrossRef]

Wickens, Michael, and J. N. Greenfield. 1973. The Econometrics of Agricultural Supply: An Application to the World Coffee Market. The Review of Economics and Statistics 55: 433-40. [CrossRef]

Worako, Tadesse K. 2012. Dynamics of Food Price Trends and Policy Options in Ethiopia. Addis Ababa: Ethiopian Development Research Institute.

World Bank. 2013. Ethiopia-Household Income, Consumption and Expenditure Survey 1999-2000-Survey Based Harmonized Indicators (SHIP) Dataset. Available online: https://microdata.worldbank.org/index.php/ catalog/1068/get-microdata (accessed on 11 June 2020).

World Bank. 2018. World Development Indicators: Country Profile. Available online: http://data.worldbank.org/ country/ethiopia (accessed on 25 January 2020).

Zerihun, Gudeta. 1999. Usufruct Rights in Land in Grain Supply Response Analysis: The Case of Ethiopia. Ethiopian Journal of Economics 5: 81-99.

Zhai, Shengying, Qihui Chen, and Wenxin Wang. 2019. What Drives Green Fodder Supply in China?-A Nerlovian Analysis with LASSO Variable Selection. Sustainability 11: 6692. [CrossRef]

(C) 2020 by the author. Licensee MDPI, Basel, Switzerland. This article is an open access article distributed under the terms and conditions of the Creative Commons Attribution (CC BY) license (http://creativecommons.org/licenses/by/4.0/). 